Review

\title{
Recent advances in VOCs and CO removal via photothermal synergistic catalysis
}

\author{
Longfu Wei a, Changlin Yu a,*, Kai Yang b, Qizhe Fan a, Hongbing Ji a,\# \\ a School of Environmental Science and Engineering, School of Chemical Engineering, Guangdong Provincial Key Laboratory of Petrochemcial Pollution \\ Processes and Control, Guangdong University of Petrochemical Technology, Maoming 525000, Guangdong, China \\ b School of Metallurgy and Chemical Engineering, Jiangxi University of Science and Technology, Ganzhou 341000, Jiangxi, China
}

\section{A R T I C L E I N F O}

\section{Article history:}

Received 14 September 2020

Accepted 9 October 2020

Available online 5 March 2021

\section{Keywords:}

Volatile organic compounds

Carbon monoxide

Photocatalysis

Thermocatalysis

Photothermal synergistic catalysis

\begin{abstract}
A B S T R A C T
Currently, air pollution is being exacerbated by rapid social, economic, and industrial development. Major air pollutants include volatile organic compounds (VOCs) and CO. Photocatalytic and thermocatalytic technology can be used to convert VOCs and CO into harmless gases effectively. Recently, photothermal synergistic catalysis has aroused much attention because of its higher performance than those of individual photocatalytic and thermocatalytic processes. There have been many reviews on separate photocatalysts and thermocatalysts for the treatment of VOCs and CO, but few reviews have focused on photothermal synergistic catalysis. In this minireview, we concentrate on recent progress into photothermal synergistic catalysis for the efficient removal of VOCs and CO. The treatment of typical VOCs (such as benzene, toluene, ethanol, formaldehyde, acetone, propylene, and propane) and CO are summarized and analyzed. Furthermore, we discuss the use of conventional reactor technology, such as fixed-bed quartz reactors, for VOCs and CO removal. We also discuss the mechanism of the photothermal synergistic catalytic removal of VOCs and CO. Finally, we present perspectives for the photothermal synergistic catalytic removal of VOCs and CO.
\end{abstract}

(C) 2021, Dalian Institute of Chemical Physics, Chinese Academy of Sciences. Published by Elsevier B.V. All rights reserved.

\section{Introduction}

Currently, the rapid development of society, economy, and industry has resulted in environmental pollution, especially, air pollution. Volatile organic compounds (VOCs), such as benzene, toluene, formaldehyde, and acetone, are important air pollutants [1-5]. VOCs can be derived from paints, organic chemi- cals, petrochemicals, and pharmaceuticals, as well as many industrial processes [6-8]. Most VOCs are toxic and damage human health [9-12]. Furthermore, VOCs also can react with the nitrogen oxides in the atmosphere and produce toxic photochemical smog [13-17]. As a result, VOCs pollution is an environmental problem that must be solved urgently, and methods to eliminate VOCs are required to improve the quality of

\footnotetext{
* Corresponding author. Tel/Fax: +86-668-2923259; E-mail: yuchanglinjx@163.com

\# Corresponding author. E-mail: jihb@mail.sysu.edu.cn

This work was supported by the National Natural Science Foundation of China (21961160741, 21962006, 21707055), Project Supported by Guangdong Province Universities and Colleges Pearl River Scholar Funded Scheme (2019), Key Research Project of Natural Science of Guangdong Provincial Department of Education (2019KZDXM010), Guangdong Provincial Key R\&D Programme (2019B110206002), Academic and Technical Leaders of the Main Disciplines in Jiangxi Province (20172BCB22018), Guangdong Basic and Applied Basic Research Foundation (2019A1515011249), Science and Technology Planned Project of Maoming (2020544), Research Fund Project of Guangdong University of Petrochemical Technology (2019rc060) and Young Innovative Talents Projects in Ordinary Universities in Guangdong Province (2019KQNCX089), Science and Technology Special Plan Project of Maoming (2020KJZX024, 2020KJZX035).

DOI: 10.1016/S1872-2067(20)63721-4 | http://www.sciencedirect.com/journal/chinese-journal-of-catalysis | Chin. J. Catal., Vol. 42, No. 7, July 2021
} 
human life.

In 1972, Fujishima et al. [18] carried out a pioneering study on photocatalytic water splitting to produce $\mathrm{H}_{2}$ and $\mathrm{O}_{2}$. Subsequently, photocatalysis arouses much attention because it does not produce secondary pollution, requires mild reaction conditions, and has low energy consumption. Using photocatalysis, $\mathrm{CO}_{2}$ reduction [19-26], water splitting [27-40], air and water purification [41-51], and bacterial decontamination [52-56] have been widely applied. In addition, the photocatalytic degradation of VOCs has become a research hot topic because of its low energy consumption for VOCs removal. For example, Huang et al. [57] synthesized a mesoporous $\mathrm{TiO}_{2}$ catalyst by a simple calcination method and used it for the purification of air polluted with benzene vapor. Because of its mesoporous structure and high benzene adsorption ability, the benzene removal efficiency was $80 \%$ under vacuum UV (VUV) irradiation, which was much higher than that of $\mathrm{P} 25 \mathrm{TiO}_{2}$. However, the photocatalytic degradation efficiency for VOCs is low because the energy available to the photocatalytic reaction is limited by the available incident light [58,59].

In contrast, thermocatalytic reactions can be promoted by increasing the temperature. These catalysts are usually based on noble metals and have high activities and good selectivities and cause no secondary pollution $[60,61]$. Unlike photocatalysts, thermocatalysts have a large energy demand, which can affect product stability and selectivity. Furthermore, the use of noble metals results in high costs, and deactivation can occur rapidly [58]. Fortunately, photothermal synergistic catalysis combines the advantages of photocatalysis and thermocatalysis, allowing the disadvantages of each individual catalytic technique to be overcome; thus, it could be a feasible approach for VOCs removal. Scheme 1 shows the applications of photothermal synergistic catalysis for the efficient removal of VOCs.

Furthermore, in addition to VOCs, CO is a widespread air pollutant with significant impact. Under normal conditions, it is a colorless, odorless, non-irritating, flammable, and explosive gaseous pollutant. It is also a common exhaust gas discharged into the air during everyday activities. As a result, CO pollution has become a major problem affecting human activities and health. CO is mainly formed by the incomplete combustion of carbonaceous materials such as coal and petroleum. At room temperature, $\mathrm{CO}$ is very stable in the atmosphere and does not react with other gas molecules. Therefore, the activation and conversion of $\mathrm{CO}$ is challenging. Yu et al. [62] reported a CO-oxidation catalyst comprising $\mathrm{Au}$ loaded on

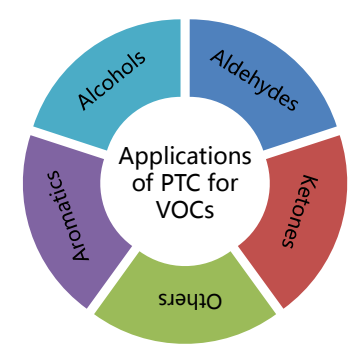

Scheme 1. Applications of photothermal synergistic catalysis for the efficient removal of VOCs. PTC: photothermal synergistic catalysis.

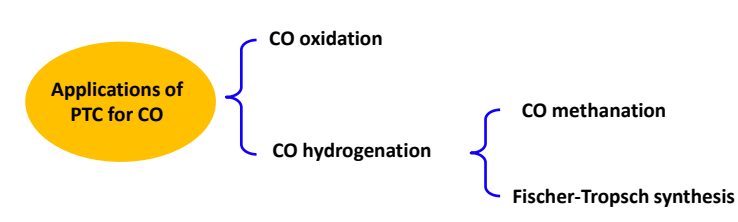

Scheme 2. Applications of photothermal synergistic catalysis for efficient removal of $\mathrm{CO}$.

well-crystallized $\mathrm{ZnCo}_{2} \mathrm{O}_{4}$ nanosheets. The catalyst showed high activity, which may be due to the strong interactions between the nanosized $\mathrm{Au}$ and $\mathrm{ZnCo}_{2} \mathrm{O}_{4}$ nanosheets. Thus, photothermal synergistic catalysis has been used for CO removal. Scheme 2 shows the applications of photothermal synergistic catalysis for the efficient removal of CO.

In this minireview, we highlight recent advances in the efficient removal of VOCs and CO using photothermal synergistic catalysis. The typical reactor type and reaction mechanisms are also presented and analyzed. In addition, future prospects for the efficient removal of VOCs and CO using photothermal catalysis are discussed. We hope that this minireview will provide direction for future research into photothermal catalysts for the efficient removal of VOCs and CO.

\section{Overview of photothermal synergistic catalysis}

\subsection{Design of synergistic photothermocatalysts}

Photocatalytic and thermocatalytic technology are widely used in the environmental, energy, and chemical fields. However, both types of catalysts have shortcomings. However, photothermal synergistic catalysis, which couples photocatalysis and thermocatalysis, is designed to overcome the individual shortcomings. In the low temperature range, the catalyst is heated to provide initial energy for the chemical reaction; subsequently, light is used to excite the catalyst to obtain a better catalytic activity than photocatalysis or thermocatalysis alone [58]. Thus, photothermal catalysis can take full advantage of light and heat energy. Furthermore, there can be synergistic effects, making it a promising new catalytic method.

A synergistic photothermocatalyst must introduce light into the thermocatalytic reaction system and heat into the photocatalytic reaction system to achieve a synergistic catalyst. Currently, there are two types of synergistic photothermocatalysts, as shown in Fig. 1. In the first system (Fig. 1(a)), a photocatalyst receives light and a thermocatalyst receives heat, and the photocatalyst and thermocatalyst are coupled to produce a photothermal synergistic effect. In this type of system, the photocatalyst is generally a semiconductor and the thermocatalyst is generally a transition or noble metal [58]. In the second type of system (Fig. 1(b)), light and heat act simultaneously on a dual-function catalyst to produce a photothermal synergistic effect. This type of catalyst is usually transition metal nanoparticles (such as group VIII metals) that exploit a unique plasmonic effect. To date, many methods, including co-precipitation, hydrothermal, and sol-gel methods, have been developed to prepare synergistic photothermocatalytic materials. 

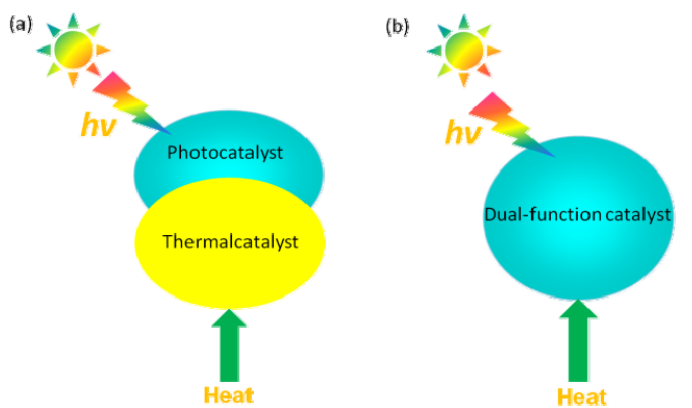

Fig. 1. Types of synergistic photothermocatalysts. (a) A coupled photocatalyst and thermocatalyst; (b) A dual-function catalyst.

\subsection{Typical reactors}

In addition to the use of a high-performance catalyst, the reactor also influences the catalytic activity. Thus, by designing the reactor rationally, high catalytic performance can be achieved. Fig. 2 shows a schematic of a typical setup for photothermal synergistic catalysis [63]. As shown, there is a photocatalytic system, thermocatalytic reaction system, and product detection system. Typically, a fixed-bed quartz reactor is used for VOCs and CO removal. The operating parameters such as light source, light intensity, wavelength, and reaction temperature affect the catalytic performance. For example, common light sources are high-pressure mercury or xenon lamps. On the basis of the optimal absorbing wavelength of the photocatalyst, we can select the appropriate light source to obtain high catalytic performance. A fixed-bed quartz reactor has some advantages, for example, it requires a small quantity of catalyst and the reactor volume is small. However, the regeneration and recharging of the catalyst are inconvenient. In addition to fixed-bed quartz reactors, batch reactors, cylindrical stainless-steel reactors, and other reactors have also been reported. However, catalyst reactivation in batch and cylindrical stainless-steel reactors is inconvenient.

\section{Applications of photothermal synergistic catalysis for the efficient removal of VOCs}

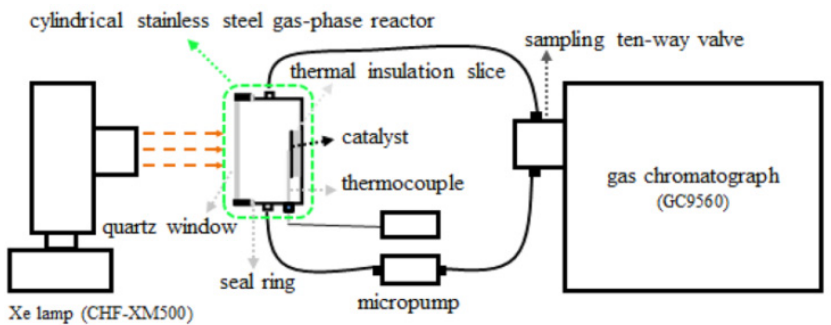

Fig. 2. Schematic of a typical photothermal synergistic catalytic setup. Reprinted with permission from Ref. [63]. Copyright (2015) American Chemical Society.

\subsection{Applications for the efficient removal of aromatics}

\subsubsection{Applications for the efficient removal of benzene}

Benzene $\left(\mathrm{C}_{6} \mathrm{H}_{6}\right)$ is the simplest aromatic hydrocarbon. At room temperature, it is a sweet smelling, flammable, colorless, and transparent liquid having a strong aromatic odor. It is also carcinogenic. Benzene is a basic petrochemical raw material, and its output and production technology are used to evaluate a country's petrochemical development level $[64,65]$. However, owing to the high volatility of benzene, it easily vaporizes in the air. Thus, benzene is a common air pollutant and can be derived from interior paint products, wood lacquers, adhesives, and various organic solvents. If large amounts of benzene enter the human body, they can cause acute and chronic benzene poisoning [66]. Further, long-term inhalation causes damage to the human nervous system. Consequently, the efficient removal of benzene has long drawn attention. Photothermal synergistic catalysis has also been used for benzene removal. Table 1 summarizes and compares the performance of photocatalytic, thermocatalytic, and synergistic photothermocatalytic techniques for VOCs degradation.

Because of its abundance, stability, and low cost, $\mathrm{TiO}_{2}$ has been widely used for photothermal synergistic catalysis $[67,68]$. However, the bandgap of $\mathrm{TiO}_{2}$ is $3.2 \mathrm{eV}$, so it can only absorb UV light [69]. Li et al. [70] synthesized anatase $\mathrm{TiO}_{2}$ nanosheets having the $\{001\}$ face as main exposed surface via a simple hydrothermal method and investigated the use of this material for the photothermal synergistic catalytic oxidation

Table 1

Summary and comparison of the performance of photocatalytic (PC), thermocatalytic (TC), and PTC degradation of VOCs.

\begin{tabular}{|c|c|c|c|c|c|c|c|c|c|c|c|c|}
\hline \multirow{2}{*}{ Catalyst } & \multirow{2}{*}{ VOCs } & \multirow{2}{*}{ Light source } & \multicolumn{3}{|c|}{ PC activity } & \multicolumn{3}{|c|}{ TC activity } & \multicolumn{3}{|c|}{ PTC activity } & \multirow{2}{*}{ Ref. } \\
\hline & & & $T /{ }^{\circ} \mathrm{C}$ & $t / \mathrm{min}$ & $C / \%$ & $T /{ }^{\circ} \mathrm{C}$ & $t / \mathrm{min}$ & $C / \%$ & $T /{ }^{\circ} \mathrm{C}$ & $t / \mathrm{min}$ & $C / \%$ & \\
\hline$\overline{\text { Anatase } \mathrm{TiO}_{2}\{001\}}$ & benzene & $\mathrm{Hg}$ & RT & 65 & 42 & - & - & - & 290 & 65 & 78 & [70] \\
\hline Rutile $\mathrm{TiO}_{2}$ & benzene & UV & RT & 160 & 50 & 280 & 160 & 18 & 280 & 160 & 70 & [71] \\
\hline $\mathrm{TiO}_{2}$ & benzene & UV & 40 & 60 & 40 & 240 & 60 & 15 & 240 & 60 & 100 & {$[72]$} \\
\hline $0.1 \mathrm{wt} \% \mathrm{Pt} / \mathrm{TiO}_{2}$ & benzene & UV & - & - & - & 240 & 60 & 89 & 240 & 30 & 100 & [72] \\
\hline $\mathrm{TiO}_{2}$ & benzene & fluorescent black light bulb & - & - & - & 140 & 300 & 30 & 140 & 300 & 86 & [73] \\
\hline $0.1 \mathrm{wt} \% \mathrm{Pt} / \mathrm{TiO}_{2}$ & benzene & fluorescent black light bulb & - & - & - & 70 & 120 & 8 & 70 & 120 & 100 & [73] \\
\hline $\mathrm{Zr}$-doped Pt/TiO ${ }_{2}$ & benzene & UV & 50 & 150 & 65 & 200 & 150 & 43 & 200 & 150 & 97 & [74] \\
\hline Pt-loaded $\mathrm{TiO}_{2} / \mathrm{ZrO}_{2}$ & benzene & Germicidal lamps & - & - & - & - & - & - & 150 & 960 & 100 & [75] \\
\hline $\mathrm{MnO}_{2}$ & benzene & $\mathrm{Xe}$ & - & - & - & - & - & - & - & 30 & 100 & [77] \\
\hline $\mathrm{Co}_{3} \mathrm{O}_{4}$ & benzene & $\mathrm{Xe}$ & - & - & - & - & - & - & - & 40 & 100 & [86] \\
\hline $\mathrm{Mn}_{x} \mathrm{FeO}_{y}-70$ & benzene & $\mathrm{Xe}$ & - & - & - & - & - & - & 244 & 25 & 100 & [87] \\
\hline
\end{tabular}


Table 1 (continued)

\begin{tabular}{|c|c|c|c|c|c|c|c|c|c|c|c|c|}
\hline \multirow{2}{*}{ Catalyst } & \multirow{2}{*}{ VOCs } & \multirow{2}{*}{ Light source } & \multicolumn{3}{|c|}{ PC activity } & \multicolumn{3}{|c|}{ TC activity } & \multicolumn{3}{|c|}{ PTC activity } & \multirow{2}{*}{ Ref. } \\
\hline & & & $T /{ }^{\circ} \mathrm{C}$ & $t / \mathrm{min}$ & $C / \%$ & $\mathrm{~T} /{ }^{\circ} \mathrm{C}$ & $t / \mathrm{min}$ & $C / \%$ & $T /{ }^{\circ} \mathrm{C}$ & $t / \mathrm{min}$ & $C / \%$ & \\
\hline $\mathrm{Pt} / \mathrm{CeO}_{2}-\mathrm{MM}$ & benzene & $\mathrm{Xe}$ & - & - & - & - & - & - & - & 25 & 100 & [91] \\
\hline $\mathrm{Pt} / \mathrm{BiVO}_{4} / \mathrm{TiO}_{2}$ & benzene & $\mathrm{Xe}$ & 30 & - & 8 & 80 & - & 28 & 80 & - & 100 & [92] \\
\hline $\mathrm{Pt} / \mathrm{LaVO}_{4} / \mathrm{TiO}_{2}$ & benzene & $\mathrm{Xe}$ & 30 & - & 12 & 70 & - & 20 & 70 & - & 100 & [94] \\
\hline $\mathrm{Pt}-\mathrm{TiO}_{2} / \mathrm{CeO}_{2}-\mathrm{MnO}_{2}$ & benzene & UV & - & - & - & - & - & - & - & 600 & 94.5 & {$[95]$} \\
\hline $\mathrm{Pt}^{-\mathrm{TiO}_{2}} / \mathrm{Ce}-\mathrm{MnO}_{x}$ & benzene & germicidal lamps & - & - & - & - & - & - & 180 & 720 & 100 & [96] \\
\hline $\mathrm{Co}_{3} \mathrm{O}_{4} / \mathrm{TiO}_{2}$ & benzene & UV-vis-IR & RT & 40 & 48 & 240 & 40 & 80 & - & 40 & 95 & [97] \\
\hline $\mathrm{MnO}_{x} / \mathrm{TiO}_{2}$ & benzene & $\mathrm{Xe}$ & 40 & 40 & 81 & 300 & 40 & 50 & - & 40 & 96.5 & [98] \\
\hline $\mathrm{CeMn}_{x} \mathrm{O}_{y} / \mathrm{TiO}_{2}$ & benzene & $\mathrm{Xe}$ & 40 & - & - & - & - & - & 250 & 20 & 100 & [99] \\
\hline OMS-2 & benzene & $\mathrm{Xe}$ & RT & 25 & 18 & - & - & - & - & 30 & 100 & [100] \\
\hline Mg-OMS-2 & benzene & $\mathrm{Xe}$ & - & - & - & 202 & - & 50 & 220 & 30 & 97.2 & [101] \\
\hline Fe-OMS-2 & benzene & $\mathrm{Xe}$ & - & - & - & 224 & - & 50 & 217 & 30 & 98.8 & [102] \\
\hline Ce-OMS-2 & benzene & $\mathrm{Xe}$ & RT & 20 & 0 & 180 & - & 70 & - & 20 & 100 & [103] \\
\hline $\mathrm{OMS}-2 / \mathrm{SnO}_{2}$ & benzene & UV-vis-IR & - & - & - & 225 & - & 50 & - & 60 & 88 & {$[104]$} \\
\hline $\mathrm{Ag} / \mathrm{F}-\mathrm{SrTiO}_{3}$ & benzene & $\mathrm{Xe}$ & - & - & - & - & - & - & 90 & 360 & $>95$ & [105] \\
\hline $\mathrm{Ag} / \mathrm{F}-\mathrm{SrTiO}_{3}$ & toluene & $\mathrm{Xe}$ & RT & 120 & 50 & 90 & 120 & 14 & 90 & 120 & 85 & [105] \\
\hline $\mathrm{Ag} / \mathrm{F}-\mathrm{SrTiO}_{3}$ & xylene & $\mathrm{Xe}$ & - & - & - & - & - & - & 90 & 360 & $>95$ & [105] \\
\hline $\mathrm{Pd}-\mathrm{CeO}_{2}$ & toluene & $\mathrm{Xe}$ & 177 & - & 50 & 222 & - & 50 & 227 & - & 82 & [106] \\
\hline $\mathrm{Pt} / \gamma-\mathrm{Al}_{2} \mathrm{O}_{3}$ & toluene & simulated sunlight & - & - & - & - & - & - & 165 & 20 & 87 & [107] \\
\hline $\mathrm{Mn}, \mathrm{Ce}$ and Co oxides $/ \mathrm{Al}_{2} \mathrm{O}_{3}$ & toluene & UV & - & - & - & 250 & 300 & 61 & 250 & 300 & 84 & [108] \\
\hline $\mathrm{SiO}_{2} @ \mathrm{Pt} @ Z \mathrm{ZrO}_{2}$ & toluene & $\mathrm{Xe}$ & RT & 60 & 18 & 150 & 60 & 80 & 150 & 60 & 100 & {$[110]$} \\
\hline Pd-Ag@CeO 2 & toluene & $\mathrm{Xe}$ & - & - & - & 130 & - & 50 & 88 & - & 50 & [111] \\
\hline $\mathrm{Ag}_{3} \mathrm{PO}_{4} / \mathrm{Ag} / \mathrm{SrTiO}_{3}$ & toluene & $\mathrm{Xe}$ & RT & 360 & 90 & 90 & 180 & 13 & 90 & 180 & 92 & [112] \\
\hline $\mathrm{Pt}-\mathrm{La}_{2} \mathrm{O}_{3} / \mathrm{TiO}_{2}$ & toluene & $\mathrm{Xe}$ & 25 & - & 85 & 150 & - & 25 & 150 & - & 100 & [113] \\
\hline Pt-rGO-TiO 2 & toluene & IR light & - & - & - & - & - & - & - & - & 95 & [114] \\
\hline $\mathrm{Pt}-\mathrm{Na} / \mathrm{TiO}_{2}$ & toluene & $\mathrm{Xe}$ & - & - & - & 150 & - & 31 & 150 & - & 82 & [115] \\
\hline $\mathrm{NiCo}_{2} \mathrm{O}_{4}$ & toluene & simulated sunlight & - & - & - & - & - & - & - & - & 93 & [117] \\
\hline $\mathrm{LaSmMnNiO}_{6}$ & toluene & Xe & - & - & - & - & - & - & 275 & - & 100 & [118] \\
\hline $\mathrm{Au} / \mathrm{TiO}_{2}$ & ethanol & $\mathrm{Xe}$ & - & - & - & - & - & - & - & - & - & [119] \\
\hline $\mathrm{Pt} / \mathrm{TiO}_{2}$ & ethanol & UV & - & - & - & 200 & - & 18 & 200 & - & 100 & [120] \\
\hline $\mathrm{MnO}_{x}-\mathrm{CeO}_{2}$ & formaldehyde & $\mathrm{Xe}$ & 25 & 180 & 42.3 & 75 & 180 & 27.1 & 75 & 180 & 90.4 & [121] \\
\hline $\mathrm{MnO}_{x} / \mathrm{Co}_{3} \mathrm{O}_{4}$ & formaldehyde & $\mathrm{Xe}$ & 25 & 180 & 20 & 80 & 180 & 36 & 80 & 180 & 84 & [122] \\
\hline graphene $/ \mathrm{MnO}_{2}$ & formaldehyde & $\mathrm{Xe}$ & - & - & - & - & 40 & 80 & - & 40 & 88 & [123] \\
\hline $\mathrm{BiOI}$ & formaldehyde & $\mathrm{Xe}$ & RT & 45 & 70 & 60 & 45 & 37.8 & 60 & 45 & 88.9 & {$[124]$} \\
\hline $\mathrm{Pt}-\mathrm{TiO}_{2} / \mathrm{SiO}_{2}$ & formaldehyde & UV & - & - & - & - & - & - & 107 & 300 & 100 & [125] \\
\hline $\mathrm{Cr}_{x} \mathrm{O} / \mathrm{TiO}_{2}$ & acetaldehyde & blue LED & - & - & - & - & - & - & 60 & 120 & 100 & [126] \\
\hline $\mathrm{WO}_{3-x}$ & acetaldehyde & UV & - & - & - & - & - & - & 60 & 80 & 100 & [127] \\
\hline OMS-2 & acetone & $\mathrm{Xe}$ & - & - & - & - & - & - & - & - & - & [100] \\
\hline Ce-OMS-2 & acetone & $\mathrm{Xe}$ & - & - & - & - & - & - & - & - & - & [103] \\
\hline $\mathrm{Pt} / \mathrm{CeO}_{2}-\mathrm{MM}$ & acetone & $\mathrm{Xe}$ & - & - & - & - & - & - & - & 20 & 95 & {$[91]$} \\
\hline nano $\mathrm{ZnO}$ & acetone & $\mathrm{Hg}$ & - & - & - & - & - & - & 240 & - & 100 & {$[129]$} \\
\hline $\mathrm{Pt} / \mathrm{TiO}_{2} /$ Silica & ethylene & UV & - & - & - & 90 & - & 34 & 90 & - & 100 & [120] \\
\hline $\mathrm{Pd} / \mathrm{TiO}_{2} /$ Silica & ethylene & UV & - & - & - & 90 & - & 19.2 & 90 & - & 100 & [130] \\
\hline $\mathrm{Au} / \mathrm{TiO}_{2} /$ Silica & ethylene & UV & - & - & - & 90 & - & 4.5 & 90 & - & 94.9 & {$[130]$} \\
\hline $\mathrm{SS}-\mathrm{Co}_{3} \mathrm{O}_{4}$ & propylene & $\mathrm{Xe}$ & - & - & - & - & - & - & - & 10 & 100 & [131] \\
\hline $\mathrm{SS}-\mathrm{Co}_{3} \mathrm{O}_{4}$ & propane & $\mathrm{Xe}$ & - & - & - & - & - & - & - & 15 & 100 & [131] \\
\hline manganese oxide & propylene & $\mathrm{Xe}$ & - & - & - & - & - & - & 205 & - & 90 & [132] \\
\hline manganese oxide & propane & $\mathrm{Xe}$ & - & - & - & - & - & - & 263 & - & 90 & {$[132]$} \\
\hline $\mathrm{Pt} / \mathrm{TiO}_{2}-\mathrm{WO}_{3}$ & propane & $\mathrm{UV} / \mathrm{Vis}$ & - & - & - & 324 & - & 70 & 90 & - & 70 & [133] \\
\hline $\mathrm{PtCu} / \mathrm{CeO}_{2}$ & n-pentane & Xe & 30 & 120 & 5 & 400 & 120 & 80 & 400 & 120 & 95 & [134] \\
\hline $\mathrm{LaMnO}_{3}$ & styrene & $\mathrm{Xe}$ & RT & 40 & 25 & 140 & 40 & 68 & 140 & 40 & 96.6 & [135] \\
\hline
\end{tabular}


(a)

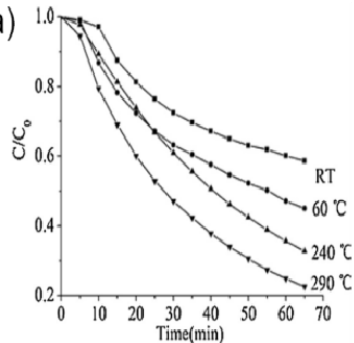

(b) $\cong$

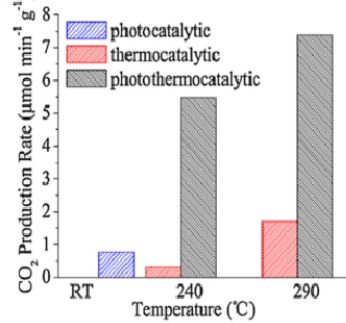

Fig. 3. (a) Change in benzene concentration with time; (b) $\mathrm{CO}_{2}$ production rate from benzene in photocatalytic, thermocatalytic, and photothermocatalytic systems. Reprinted with permission from Ref. [70]. Copyright (2016) Elsevier.

of gas-phase benzene under irradiation by a Hg lamp. Fig. 3(a) shows the change in the benzene concentration with time at different temperatures. At room temperature, the benzene removal efficiency of the $\mathrm{TiO}_{2}$ nanosheets was about $42 \%$ after 65 min irradiation. With increase in reaction temperature from room temperature to $290{ }^{\circ} \mathrm{C}$, the removal efficiency reached $78 \%$. Thus, increasing the reaction temperature increases the photothermocatalytic activity. Fig. 3(b) compares the $\mathrm{CO}_{2}$ production rates of photocatalytic, thermocatalytic, and photothermocatalytic processes at room temperature, $240{ }^{\circ} \mathrm{C}$, and $290{ }^{\circ} \mathrm{C}$. At room temperature, the $\mathrm{CO}_{2}$ production rate of the photocatalyst was $0.77 \mu \mathrm{mol} \mathrm{min}{ }^{-1} \mathrm{~g}^{-1}$. At $290^{\circ} \mathrm{C}$, the $\mathrm{CO}_{2}$ production rates of the thermocatalyst and photothermocatalyst

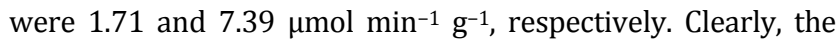
photothermocatalyst performance was much higher than those of the photocatalyst and thermocatalyst, and this suggested that a synergistic effect was involved in the photothermocatalytic process. Specifically, in the photothermocatalyst, the Mars-van Krevelen redox cycle between $\mathrm{TiO}_{2}$ and $\mathrm{TiO}_{2-x}$ is accelerated, thus enhancing the degradation of benzene. In a similar work, Zeng et al. [71] reported a rutile $\mathrm{TiO}_{2}$ nanorod array synergistic photothermocatalyst for the efficient removal of gaseous benzene. The unique $\mathrm{TiO}_{2}$ nanorod array has few grain boundaries, which would weaken the lattice scattering effect of the electrons $\left(\mathrm{e}^{-}\right)$and suppress the recombination of $\mathrm{e}^{-}$and hole $\left(\mathrm{h}^{+}\right)$pairs. With increase in reaction temperature, the removal efficiency of benzene first increased and then decreased, and a reaction temperature of $160{ }^{\circ} \mathrm{C}$ yielded the highest catalytic activity. At higher temperatures $\left(>160^{\circ} \mathrm{C}\right), \mathrm{H}_{2} \mathrm{O}$ desorption suppressed the formation of $\bullet \mathrm{OH}$, resulting in a reduction in the catalytic performance.

Li et al. [72] also studied the use of $\mathrm{TiO}_{2}$ for photothermal synergistic catalytic benzene removal under UV light. The photocatalytic benzene removal efficiency under UV irradiation at $40{ }^{\circ} \mathrm{C}$ was about $40 \%$, whereas the thermocatalytic benzene removal efficiency at $240{ }^{\circ} \mathrm{C}$ was $15 \%$. Interestingly, at $240{ }^{\circ} \mathrm{C}$, benzene was completely degraded via photothermal synergistic catalysis with UV irradiation, unlike the photocatalytic and thermocatalytic processes. This result was possible because the lattice oxygen in $\mathrm{TiO}_{2}$ decreased the activation energy for benzene oxidation. In a further study, Li et al. [72] synthesized a 0.1 $w \mathrm{t} \% \mathrm{Pt} / \mathrm{TiO}_{2}$ catalyst for photothermal synergistic catalytic benzene oxidation. The benzene was completely converted to

$\mathrm{CO}_{2}$ and $\mathrm{H}_{2} \mathrm{O}$ under UV irradiation within 30 min. Further, Zeltner et al. [73] prepared porous $\mathrm{TiO}_{2}$ by a sol-gel technique and then loaded Pt nanoparticles (NPs) on the porous $\mathrm{TiO}_{2}$. The resulting synergistic photothermocatalyst was used for benzene oxidation, and the $0.1 \mathrm{wt} \% \mathrm{Pt} / \mathrm{TiO}_{2}$ catalyst showed much higher activity than that of $\mathrm{TiO}_{2}$ alone. The role of $\mathrm{Pt}$ in the thermocatalytic reaction was as an additive, whereas, in the photocatalytic reaction, Pt provided reaction sites to increase the catalytic performance.

Ren et al. [74] fabricated $\mathrm{Zr}$-doped $\mathrm{TiO}_{2}$ via a co-precipitation method and then loaded $0.5 \mathrm{wt} \% \mathrm{Pt}$ on the $\mathrm{Zr}$-doped $\mathrm{TiO}_{2}$ via an incipient wetness impregnation to prepare a $\mathrm{Zr}$-doped $\mathrm{Pt} / \mathrm{TiO}_{2}$ catalyst. For photothermal synergistic catalytic benzene oxidation, this catalyst exhibited higher catalytic activity than the photocatalytic and thermocatalytic processes. Thus, the $\mathrm{Zr}$ dopant enhanced the activity of the $\mathrm{Pt} / \mathrm{TiO}_{2}$ catalyst remarkably. In a further study, Ren et al. [75] reported a Pt-loaded $\mathrm{TiO}_{2} / \mathrm{ZrO}_{2}$ catalyst for photothermal synergistic catalytic benzene oxidation. The results revealed the synergistic effect between the photocatalytic and thermocatalytic processes. At a high concentration of benzene $\left(1000 \mathrm{mg} \mathrm{m}^{-3}\right)$ and under the illumination of a germicidal lamp, the Pt-loaded $\mathrm{TiO}_{2} / \mathrm{ZrO}_{2}$ catalyst completely degraded benzene to $\mathrm{CO}_{2}$ and $\mathrm{H}_{2} \mathrm{O}$ within $960 \mathrm{~min}$. A schematic the photothermocatalytic process over the Pt-loaded $\mathrm{TiO}_{2} / \mathrm{ZrO}_{2}$ catalyst is shown in Fig. 4. A Schottky junction is produced at the interface of Pt and $\mathrm{TiO}_{2}$ on the Pt-loaded $\mathrm{TiO}_{2} / \mathrm{ZrO}_{2}$ catalyst. The $\mathrm{e}^{-}$are then transferred from the conduction band of $\mathrm{TiO}_{2}$ to Pt on UV irradiation, and the $\mathrm{h}^{+}$are the major active species for benzene oxidation. In addition, Pt contributed to benzene oxidation. Therefore, the Pt-loaded $\mathrm{TiO}_{2} / \mathrm{ZrO}_{2}$ catalyst exhibited outstanding photothermocatalytic performance.

Usually, metal oxides such as $\mathrm{MnO}_{2}$ show thermocatalytic activity at high reaction temperatures [76]. Li et al. [77] synthesized ramsdellite $\mathrm{MnO}_{2}$ hollow spheres comprising closely stacked nanosheets ( $\mathrm{R}-\mathrm{MnO}_{2}-\mathrm{HS}$ ) for photothermal synergistic catalytic benzene oxidation. The diameter of the hollow nanospheres was about $1 \mu \mathrm{m}$ and the thickness of the nanosheets was about $7.8 \mathrm{~nm}$ (Figs. 5(a) and 5(b)). The high-resolution

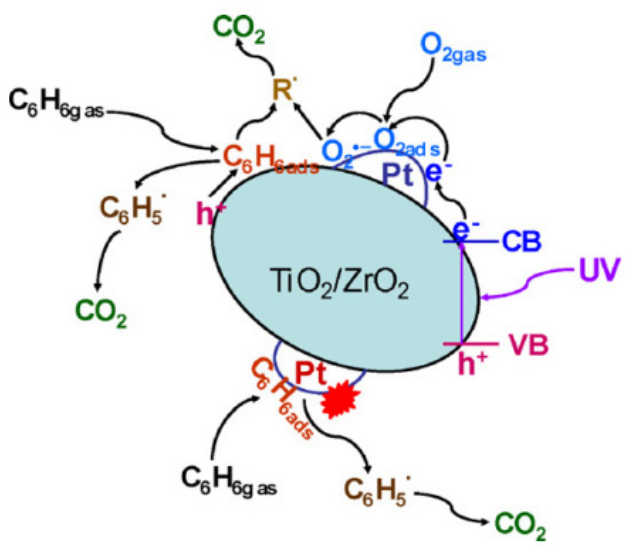

Fig. 4. Schematic of photothermal synergistic catalysis for benzene oxidation on Pt-loaded $\mathrm{TiO}_{2} / \mathrm{ZrO}_{2}$ catalyst. Reprinted with permission from Ref. [75]. Copyright 2012, Elsevier. 
(a)

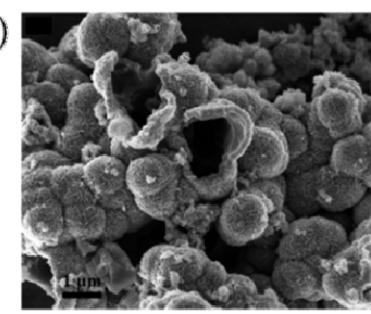

(c)

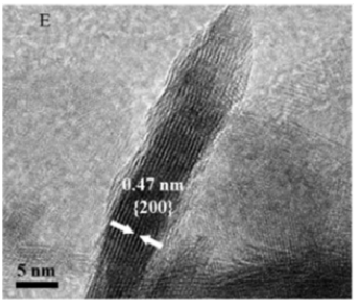

(b)

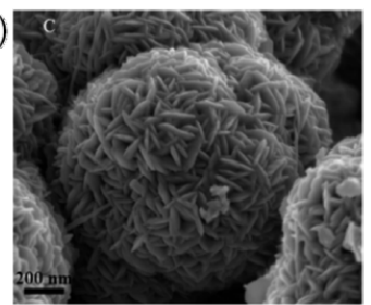

(d)

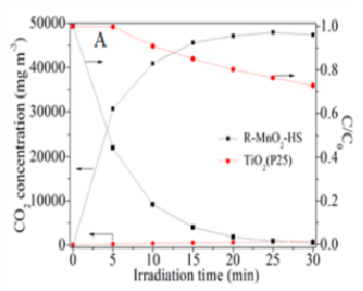

Fig. 5. Scanning electron microscopy images $(\mathrm{a}, \mathrm{b})$ and high-resolution transmission electron microscopy image (c) of $\mathrm{R}-\mathrm{MnO}_{2}-\mathrm{HS}$; (d) $\mathrm{CO}_{2}$ concentration and benzene conversion (concentration/initial concentration $\left(C / C_{0}\right)$ ) over $\mathrm{R}-\mathrm{MnO}_{2}-\mathrm{HS}$ and $\mathrm{TiO}_{2}$ (P25) catalysts under full solar spectrum irradiation. Reprinted with permission from Ref. [77]. Copyright (2019) American Chemical Society.

transmission electron microscopy (HRTEM) image shows the lattice fringes having an interplanar spacing of $0.47 \mathrm{~nm}$ (Fig. 5(c)), which could be ascribed to the characteristic $\{200\}$ facet of the nanosheets. The results for the $\mathrm{R}-\mathrm{MnO}_{2}-\mathrm{HS}$ and $\mathrm{TiO}_{2}$ (P25) catalysts are shown in Fig. 5(d), and benzene was completely converted within $30 \mathrm{~min}$ under Xe lamp irradiation. However, P25 showed a removal efficiency of only $27 \%$ after 30 min. Furthermore, the $\mathrm{CO}_{2}$ concentration of $\mathrm{R}-\mathrm{MnO}_{2}-\mathrm{HS}$ was much higher than that of P25. Because of the lattice oxygen activity and reducibility of $\mathrm{MnO}_{2}$ to $\mathrm{MnO}_{2}-x, \mathrm{R}-\mathrm{MnO}_{2}-\mathrm{HS}$ exhibited high thermocatalytic activity via the Mars-van Krevelen redox mechanism. With the addition of novel photoactivity, $\mathrm{R}-\mathrm{MnO}_{2}-\mathrm{HS}$ showed excellent photothermocatalytic performance compared with P25.

$\mathrm{Co}_{3} \mathrm{O}_{4}$ is a p-type semiconductor with the band gap of 1.2-2.1 eV and demonstrates high photocatalytic performance for $\mathrm{CO}_{2}$ reduction and water splitting [78-82]. Furthermore, $\mathrm{Co}_{3} \mathrm{O}_{4}$ also exhibits good thermocatalytic performance for environmental remediation [83-85]. Li et al. [86] fabricated $\mathrm{Co}_{3} \mathrm{O}_{4}$ mesoporous nanorods $\left(\mathrm{Co}_{3} \mathrm{O}_{4}-\mathrm{MNR}\right)$ having $\mathrm{Co}^{2+}$ vacancies for the photothermal synergistic catalytic benzene oxidation under UV-vis-infrared (IR) and vis-IR irradiation. Compared with $\mathrm{Co}_{3} \mathrm{O}_{4}$-Aladdin and $\mathrm{P} 25$, the $\mathrm{Co}_{3} \mathrm{O}_{4}$-MNR catalyst demonstrated the highest photothermocatalytic performance, possibly because the $\mathrm{Co}^{2+}$ vacancy defects increased the activity of $\mathrm{Co}_{3} \mathrm{O}_{4}$. In a further study, Li and coworkers reported a mesoporous amorphous manganese iron oxide $\left(\mathrm{Mn}_{x} \mathrm{FeO}_{y}-70\right)$ which was prepared from the redox reaction of iron (II) acetate and $\mathrm{KMnO}_{4}$ at $70{ }^{\circ} \mathrm{C}$ for photothermal synergistic catalytic benzene removal [87]. The photothermocatalytic performance was much higher than that of $\mathrm{MnO}_{x}-\mathrm{Fe}_{2} \mathrm{O}_{3}-180,0.5 \mathrm{wt} \% \mathrm{Pt} / \mathrm{Al}_{2} \mathrm{O}_{3}$, and $0.5 \mathrm{wt} \% \mathrm{Pd} / \mathrm{Al}_{2} \mathrm{O}_{3}$. Possibly, the lattice of the $\mathrm{Mn}_{x} \mathrm{FeO}_{y}-70$ increased the photothermocatalytic performance and improved the catalyst stability.

Currently, noble-metal-loaded catalysts are widely used in industrial VOCs removal at high temperatures. Furthermore, some noble metals show the surface plasmon resonance (SPR) effect, which can increase the catalytic performance for reactions such as $\mathrm{CO}_{2}$ reduction and water splitting [88-90]. Li and coworkers [91] synthesized Pt NPs loaded on a micro-sized mesoporous $\mathrm{CeO}_{2}$ to produce a $\mathrm{Pt} / \mathrm{CeO}_{2}-\mathrm{MM}$ catalyst for photothermocatalytic benzene removal. The $\mathrm{Pt} / \mathrm{CeO}_{2}-\mathrm{MM}$ catalyst completely oxidized the benzene within a short period. The SPR absorption of Pt produced hot electrons, which increased photoactivation. Therefore, both the outstanding thermocatalytic performance and SPR absorption of Pt contributed to the high photothermocatalytic performance. Li and coworkers also prepared a $\mathrm{BiVO}_{4} / \mathrm{TiO}_{2}$ catalyst for photocatalytic benzene oxidation and found that the stability and activity of the catalyst increased with increase in temperature [92]. Subsequently, Li et al. [92] loaded Pt NPs on a $\mathrm{BiVO}_{4} / \mathrm{TiO}_{2}$ catalyst to enhance the photothermocatalytic performance. When the Pt loading amount was $1 \%$, the $\mathrm{Pt} / \mathrm{BiVO}_{4} / \mathrm{TiO}_{2}$ catalyst exhibited the highest photothermocatalytic performance because of the outstanding thermocatalytic activity at low temperatures. Further, it was reported that $\mathrm{LaVO}_{4} / \mathrm{TiO}_{2}$ showed high performance for the photocatalytic oxidation of benzene under UV-vis irradiation [93]. Furthermore, Pt is often used in thermocatalytic reaction and exhibits high thermocatalytic performance. In a similar work, $\mathrm{Li}$ and coworker [94] synthesized a novel Pt/LaVO $4 / \mathrm{TiO}_{2}$ catalyst for photothermal synergistic catalytic benzene oxidation. At $70{ }^{\circ} \mathrm{C}$, benzene was completely oxidized into $\mathrm{CO}_{2}$ and $\mathrm{H}_{2} \mathrm{O}$ under simulated solar light. A schematic of photothermal synergistic catalytic benzene oxidation over the $\mathrm{Pt} / \mathrm{LaVO}_{4} / \mathrm{TiO}_{2}$ catalyst is shown in Fig. 6. Therefore, there was a synergistic effect between $\mathrm{Pt}$ and $\mathrm{LaVO}_{4} / \mathrm{TiO}_{2}$ that enhanced the photothermocatalytic performance.

Ren and coworkers [95] synthesized a $\mathrm{CeO}_{2}-\mathrm{MnO}_{2}$ oxygen-storage material via a sol-gel method and then loaded this material with $\mathrm{TiO}_{2}$ and $\mathrm{Pt}$ NPs to fabricate a Pt-TiO $2 / \mathrm{CeO}_{2}-\mathrm{MnO}_{2}$ catalyst. The $1.6 \%$ Pt- $40 \% \quad \mathrm{TiO}_{2} / \mathrm{CeO}_{2}$ $\mathrm{MnO}_{2}$ showed excellent photothermocatalytic performance, and the benzene removal efficiency was $94.5 \%$ after $10 \mathrm{~h}$. In this catalyst, $\mathrm{Mn}$ infiltrated the $\mathrm{TiO}_{2}$ and $\mathrm{CeO}_{2}$ lattices to produce a solid solution, and the Pt NPs were uniformly dispersed on the surface of catalyst, resulting in high photothermocata-

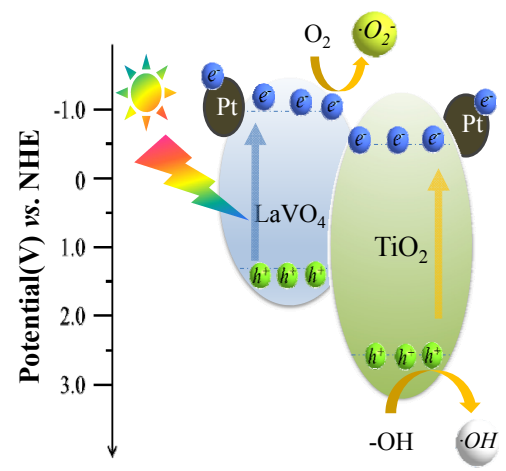

Fig. 6. Schematic of photothermal synergistic catalysis for benzene oxidation on the $\mathrm{Pt} / \mathrm{LaVO}_{4} / \mathrm{TiO}_{2}$ catalyst. 
lytic performance. In addition, Ren et al. [96] reported a $1 \%$ $\mathrm{Pt}-40 \% \mathrm{TiO}_{2} / \mathrm{Ce}-\mathrm{MnO}_{x}$ catalyst for the photothermocatalytic degradation of benzene. The $\mathrm{Ce}-\mathrm{MnO}_{x}$ catalyst acts as the thermocatalyst and contains lattice oxygen and surface active oxygen that enhance the oxidation ability toward benzene. Further, the $\mathrm{Pt}$ and $\mathrm{TiO}_{2}$ components act as thermocatalyst and photocatalyst, respectively. Therefore, this catalyst also shows a photothermal synergistic catalysis effect for benzene oxidation.

$\mathrm{TiO}_{2}$ is a common photocatalyst, and $\mathrm{CeO}_{2}$ is an effective thermocatalyst. Based on the above analysis, $\mathrm{Li}$ and coworkers synthesized a $\mathrm{TiO}_{2} / \mathrm{CeO}_{2}$ nanocomposite catalyst for the photothermocatalytic degradation of benzene [63]. $\mathrm{The}^{\mathrm{TiO}_{2}} / \mathrm{CeO}_{2}$ nanocomposite catalyst demonstrated high photothermocatalytic performance because of the synergistic effect between the $\mathrm{TiO}_{2}$ photocatalyst and the $\mathrm{CeO}_{2}$ thermocatalyst. A schematic illustration of photothermal synergistic catalytic benzene oxidation over the $\mathrm{TiO}_{2} / \mathrm{CeO}_{2}$ catalyst is shown in Fig. 7(a). In a further study, Li et al. [97] prepared a $\mathrm{Co}_{3} \mathrm{O}_{4} / \mathrm{TiO}_{2}$ nanocomposite catalyst with different $\mathrm{Co} / \mathrm{Ti}$ molar ratios. When the $\mathrm{Co} / \mathrm{Ti}$ molar ratio was 0.3 , the $\mathrm{Co}_{3} \mathrm{O}_{4} / \mathrm{TiO}_{2}$ nanocomposite catalyst showed the highest photothermocatalytic performance for benzene oxidation. Fig. 7(b) shows a schematic of the $\mathrm{Co}_{3} \mathrm{O}_{4} / \mathrm{TiO}_{2}$ catalyst under UV-vis-IR irradiation. Li and coworkers [98] also synthesized a $\mathrm{MnO}_{x} / \mathrm{TiO}_{2}$ nanocomposite catalyst for photothermal synergistic catalytic benzene oxidation. The light energy introduced to the $\mathrm{MnO}_{x} / \mathrm{TiO}_{2}$ nanocomposite catalyst was transformed into thermal energy, thus increasing the reaction temperature and resulting in outstanding photothermocatalytic performance and durability. $\mathrm{Li}$ and coworkers [99] also prepared a $\mathrm{CeMn}_{x} \mathrm{O}_{y} / \mathrm{TiO}_{2}$ nanocomposite catalyst for benzene oxidation. The benzene was completely
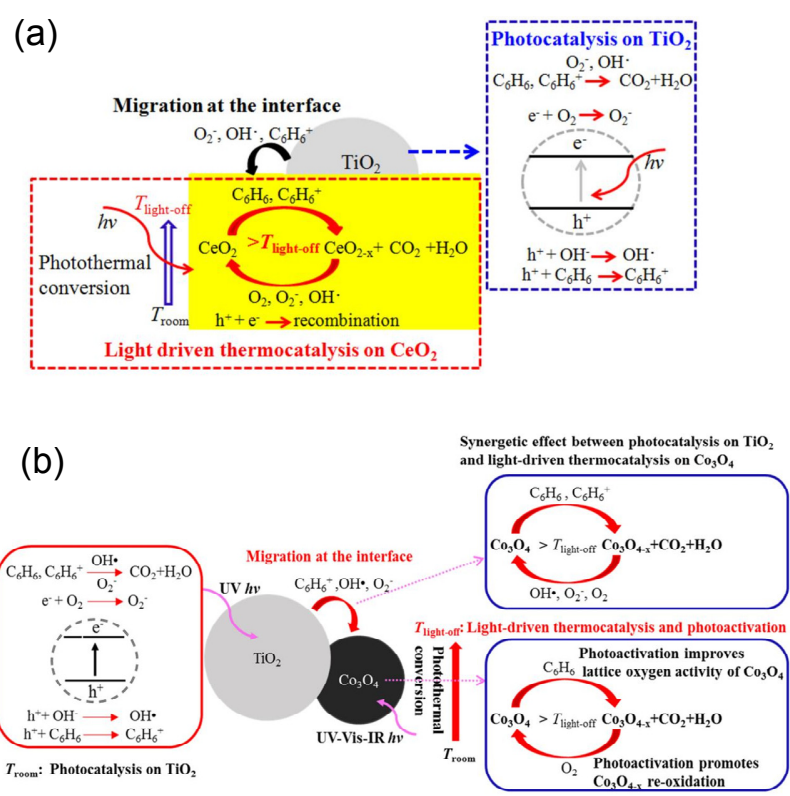

Fig. 7. Schematic of photothermal synergistic catalysis for benzene oxidation over $\mathrm{TiO}_{2} / \mathrm{CeO}_{2}$ (a) and $\mathrm{Co}_{3} \mathrm{O}_{4} / \mathrm{TiO}_{2}$ (b) catalysts. (a) Reprinted with permission from Ref. [63]. Copyright 2015, American Chemical Society; (b) Reprinted with permission from Ref. [97]. Copyright (2018) American Chemical Society. oxidized to $\mathrm{CO}_{2}$ and $\mathrm{H}_{2} \mathrm{O}$ within 20 min.

Octahedral molecular sieve (OMS-2), a type of manganese oxide with edge and corner-sharing $\mathrm{MnO}_{6}$ octahedra, has been used for thermocatalytic reactions [100]. Li and coworkers [100] synthesized an OMS-2 nanorod catalyst via a facile method for photothermal synergistic catalytic benzene degradation. The oxygen vacancy defects in OMS-2 could be modulated to enhance catalytic performance, and OMS-2 demonstrated outstanding photothermocatalytic performance under full solar spectrum irradiation. Within a short time, the benzene was completely oxidized to $\mathrm{CO}_{2}$ and $\mathrm{H}_{2} \mathrm{O}$. A schematic of photothermal synergistic catalytic benzene oxidation over the OMS-2 catalyst is shown in Fig. 8. On introducing light energy, the OMS-2 catalyst was transformed to thermal energy and increased the reaction temperature, thus enhancing the photothermocatalytic performance. In a further study, Li et al. [101] reported that doping OMS-2 with Mg could enhance the photothermocatalytic performance for benzene oxidation. The addition of a small amount of Mg dopant resulted in significantly enhanced photothermocatalytic activity compared with that of OMS-2. The optimally doped OMS-2 catalyst achieved 97.2\% benzene conversion within $30 \mathrm{~min}$, which is much higher than those of OMS-2 and P25. The doping with Mg enhanced the lattice oxygen activity of OMS-2, thus resulting in increased photothermocatalytic performance. Subsequently, $\mathrm{Li}$ and coworkers [102] synthesized Fe-doped OMS-2 having different $\mathrm{Fe} / \mathrm{Mn}$ molar ratios. The Fe-doped catalyst showed significantly improved photothermocatalytic benzene oxidation performance.

Li and coworkers [103] synthesized a nanostructured Ce-ion-substituted OMS-2 (CM-120) catalyst via a simple hydrothermal method. This catalyst showed strong absorption over the full solar spectrum and transformed the solar energy to thermal energy. The CM-120 catalyst was used for the photothermocatalytic degradation of benzene, and the benzene removal efficiency reached $100 \%$ within 20 min, which is much higher than those of $\mathrm{CeO}_{2} / \mathrm{OMS}-2$ and pure OMS-2. However, the benzene could not be converted to $\mathrm{CO}_{2}$ and $\mathrm{H}_{2} \mathrm{O}$ photocatalytically with the CM-120 catalyst at room temperature. Furthermore, thermocatalytic reaction with CM-120 follows the well-known Mars-van Krevelen mechanism. Therefore, the CM-120 must involve a new mechanism of solar light driven thermocatalysis to achieve the photothermocatalytic effect. In a further study, Li et al. [104] prepared an $\mathrm{OMS}-2 / \mathrm{SnO}_{2}$ nano-

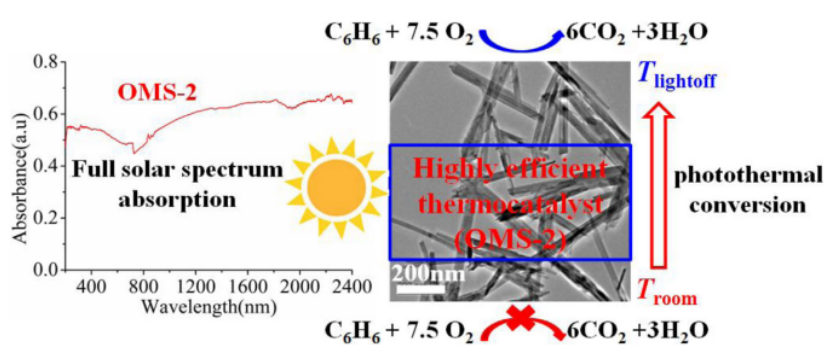

Fig. 8. Schematic of photothermal synergistic catalysis over the OMS-2 catalyst. Reprinted with permission from Ref. [100]. Copyright (2015) Elsevier. 
composite catalyst via a simple redox reaction. The OMS-2/SnO 2 catalyst exhibited outstanding photothermocatalytic activity for benzene oxidation. In this system, photocatalysis over $\mathrm{SnO}_{2}$ and light-driven thermocatalysis on OMS-2 contributed to a photothermocatalytic effect that enhanced the catalytic activity.

Rui and coworkers prepared an Ag/F-codoped $\mathrm{SrTiO}_{3}$ (STO) catalyst by a simple hydrothermal method [105]. The UV-vis absorption spectra of the catalysts are shown in Fig. 9(a). Clearly, the Ag/F-STO and Ag-STO catalysts showed visible light absorption, possibly as a result of SPR in the Ag NPs. The Ag/F-STO catalyst was used for photothermocatalytic benzene oxidation, and the benzene removal efficiency reached 95\% within $6 \mathrm{~h}$. A schematic of photothermal synergistic catalytic benzene oxidation over the Ag/F-STO catalyst is shown in Fig. 9(b). The F-dopant enhanced the visible light response, and the $\mathrm{Ag}$ improved the visible light absorption and suppressed charge recombination, resulting in high photothermocatalytic activity.

\subsubsection{Applications for the efficient removal of toluene}

Toluene $\left(\mathrm{C}_{7} \mathrm{H}_{8}\right)$ is a colorless transparent liquid having an odor similar to benzene. It is also a common air pollutant. Thus, catalytic toluene oxidation has aroused much attention. The localized surface plasmon resonance (LSPR) effect is usually found in noble metal nanoparticles and can be used to harvest photon energy for the reaction. Si and coworkers prepared a $\mathrm{Pd}-\mathrm{CeO}_{2}$ catalyst by a simple reduction method. In this catalyst, there are many active interfaces that enhance the catalytic activity via the LSPR hot electrons produced under visible light irradiation [106]. Rui and coworkers [105] reported a Ag/F-codoped $\mathrm{SrTiO}_{3}$ catalyst for the photothermocatalytic oxidation of toluene and xylene, and the toluene and xylene removal efficiencies were greater than $95 \%$ at $90{ }^{\circ} \mathrm{C}$. Thus, codoping with Ag and F contributes to achieving excellent photothermocatalytic activity.

Jia and coworkers [107] prepared a $\mathrm{Pt} / \gamma-\mathrm{Al}_{2} \mathrm{O}_{3}$ catalyst by a facile method. It is well known that the number of Pt active sites is related to the catalytic activity, and the number of $\mathrm{Pt}$ active sites is affected by the dispersion and the loading amount of Pt NPs. A 1.81 wt $\%$ Pt $/ \gamma-\mathrm{Al}_{2} \mathrm{O}_{3}$ catalyst exhibited high photothermocatalytic activity, and the toluene removal efficiency was $87 \%$ at a solar radiation power density of 320 $\mathrm{mW} \mathrm{cm}{ }^{-2}$ (Fig. 10). The average Pt size and percentage of active Pt sites of $1.81 \mathrm{wt} \% \mathrm{Pt} / \gamma-\mathrm{Al}_{2} \mathrm{O}_{3}$ were $1.4 \mathrm{~nm}$ and $1.102 \%$, re- (a)

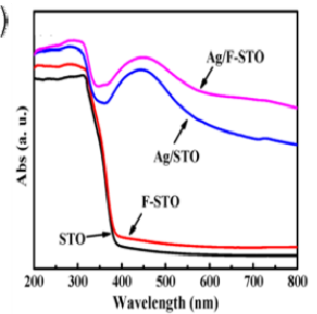

(b)

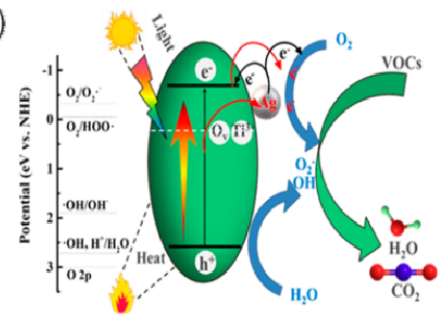

Fig. 9. (a) UV-vis absorption spectra of the catalysts; (b) Schematic illustration of photothermal synergistic catalysis for VOCs on $\mathrm{Ag} / \mathrm{F}$-codoped $\mathrm{SrTiO}_{3}$ catalysts. Reprinted with permission from Ref. [105]. Copyright (2018) American Chemical Society.

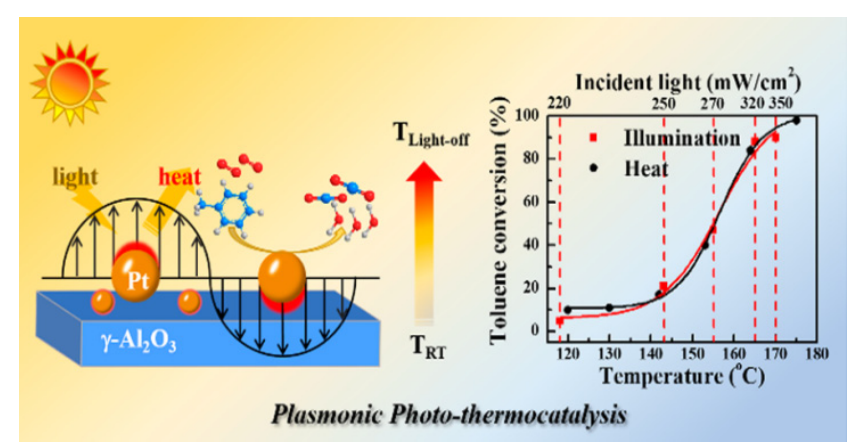

Fig. 10. Schematic of photothermal synergistic catalysis for VOCs degradation over a Pt $/ \gamma-\mathrm{Al}_{2} \mathrm{O}_{3}$ catalyst. Reprinted with permission from Ref [107]. Copyright (2018) American Chemical Society.

spectively. The SPR effect of the Pt NPs played an important role in achieving the outstanding catalytic activity under irradiation by the full solar spectrum. Akarsu et al. [108] prepared $\mathrm{Mn}, \mathrm{Ce}$, and $\mathrm{Co}$ oxides supported on $\mathrm{Al}_{2} \mathrm{O}_{3}$ and investigated their use for toluene oxidation. The photothermocatalytic activity was much higher than that of the thermocatalytic activity.

Core/shell structures have been widely used in photocatalytic and thermal catalytic reactions because they offer a large number of active sites and have a large surface area for adsorption [109]. Ji and coworkers [110] synthesized a core/shell $\mathrm{SiO}_{2} @ \mathrm{Pt} @ \mathrm{ZrO}_{2}$ nanostructure via a sequential deposition process (Fig. 11(a)). The core and shell $\mathrm{SiO}_{2}$ and $\mathrm{ZrO}_{2}$ layers, respectively, were decorated with Pt NPs. Fig. 11(b) shows an HRTEM image of the $\mathrm{SiO}_{2} @ \mathrm{Pt} @ \mathrm{ZrO}_{2}$ material. The $\mathrm{ZrO}_{2}$ layer had an average thickness of about $6 \mathrm{~nm}$ and was amorphous. Under light irradiation, the toluene removal efficiency was approximately $100 \%$ at $150{ }^{\circ} \mathrm{C}$ for the photothermal reaction, much higher than that of the thermocatalytic reaction. A schematic of the synergistic catalytic process for VOCs degradation on the $\mathrm{SiO}_{2} @ \mathrm{Pt} @ \mathrm{ZrO}_{2}$ catalyst is shown in Fig. 11(c). In this catalyst, $\mathrm{Pt}$ and $\mathrm{ZrO}_{2}$ are in close contact, which maximizes the metal-support interaction and promotes charge separation, thus resulting in excellent catalytic performance. In a similar work, Si et al. [111] reported a Pd-Ag@CeO 2 core/shell struc- (a)

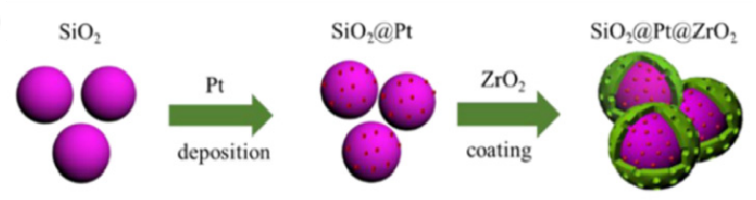

(b)

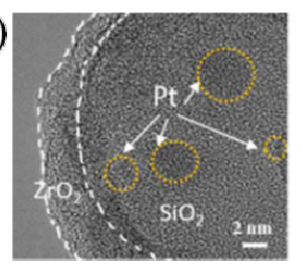

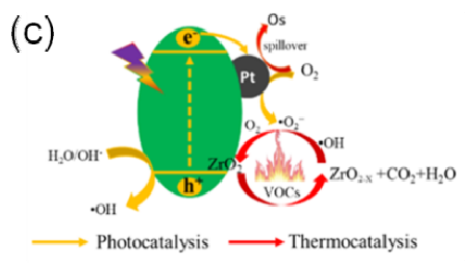

Fig. 11. (a) Synthesis of core/shell $\mathrm{SiO}_{2} @ \mathrm{Pt} @ \mathrm{ZrO}_{2}$ nanostructures; (b) High-resolution transmission electron microscopy image of the $\mathrm{SiO}_{2} @ \mathrm{Pt} @ \mathrm{ZrO}_{2}$ catalyst; (c) Schematic of photothermal synergistic catalysis over the $\mathrm{SiO}_{2} @ \mathrm{Pt} @ \mathrm{ZrO}_{2}$ catalyst for VOCs removal. Reprinted with permission from Ref. [110]. Copyright (2019) American Chemical Society. 
ture for the photothermal synergistic catalysis of toluene. To achieve a toluene removal efficiency of $50 \%$, a reaction temperature of only $88^{\circ} \mathrm{C}$ was required, which was much lower than that required for the thermocatalytic process. Both Pd and Ag NPs showed LSPR effects, thus producing hot electrons and enhancing the catalytic performance.

Z-scheme heterojunctions are widely used in photocatalysis owing to their high charge separation and strong redox ability. Ji and coworker [112] prepared a Z-scheme $\mathrm{Ag}_{3} \mathrm{PO}_{4} / \mathrm{Ag} / \mathrm{SrTiO}_{3}$ heterojunction catalyst bridged via Ag NPs. The photothermocatalytic toluene removal efficiency was $92 \%$ at $90{ }^{\circ} \mathrm{C}$, which was much higher than the photocatalytic and thermocatalytic activities. Fig. 12 shows a schematic of the photothermocatalytic degradation of VOCs on the $\mathrm{Ag}_{3} \mathrm{PO}_{4} / \mathrm{Ag} / \mathrm{SrTiO}_{3}$ catalyst. The Z-scheme $\mathrm{Ag}_{3} \mathrm{PO}_{4} / \mathrm{Ag} / \mathrm{SrTiO}_{3}$ heterojunction had a strong visible light response and enhanced reduction and oxidation ability to produce the oxidative species such as $\bullet \mathrm{O}_{2}{ }^{-}$and $\bullet \mathrm{OH}$, resulting in excellent photothermocatalytic activity.

$\mathrm{Liu}$ and coworkers reported a Pt- $\mathrm{La}_{2} \mathrm{O}_{3} / \mathrm{TiO}_{2}$ catalyst for photothermal synergistic catalytic toluene oxidation to $\mathrm{CO}_{2}$ and $\mathrm{H}_{2} \mathrm{O}$ [113]. The Pt was mainly involved in oxygen adsorption and did not change the $\mathrm{TiO}_{2}$ phase. With increase in reaction temperature, the toluene removal efficiency increased.

Jia and coworkers [114] prepared a hybrid Pt-rGO-TiO (rGO: reduced graphene oxide) catalyst that showed a broad light absorption ability. Under IR irradiation, the toluene removal efficiency was $95 \%$ and the photothermal conversion efficiency was $14.1 \%$. A schematic illustration of the photothermal synergistic catalytic process over the Pt-rGO-TiO 2 catalyst is shown in Fig. 13. In this catalyst, light is effectively converted to heat, and the $2 \mathrm{D}$ rGO sheets enhance the adsorption capacity of $\mathrm{Pt}_{-} \mathrm{TiO}_{2}$, thus resulting in superior photothermocatalytic performance. Si et al. [115] synthesized a $\mathrm{NaOH}$-promoted $\mathrm{Pt} / \mathrm{TiO}_{2}$ catalyst via a simple impregnation method with $\mathrm{NaOH}$. The Pt-Na/ $\mathrm{TiO}_{2}$ catalyst showed excellent photothermocatalytic activity for toluene conversion. The positively charged Pt species were the main active sites for toluene oxidation. Furthermore, the $\mathrm{NaOH}$ stabilized the Pt clusters,

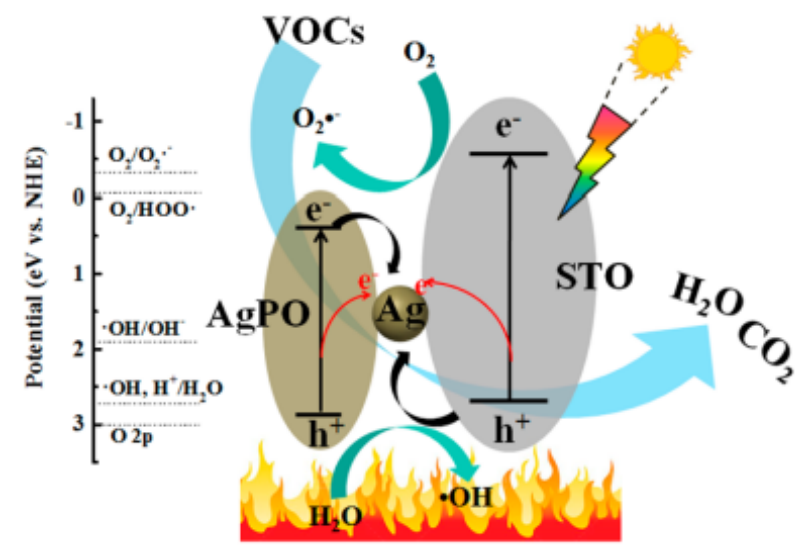

Fig. 12. Schematic of photothermal synergistic catalytic VOCs degradation over the $\mathrm{Ag}_{3} \mathrm{PO}_{4} / \mathrm{Ag} / \mathrm{SrTiO}_{3}$ catalyst. Reprinted with permission from Ref. [112]. Copyright (2019) American Chemical Society.

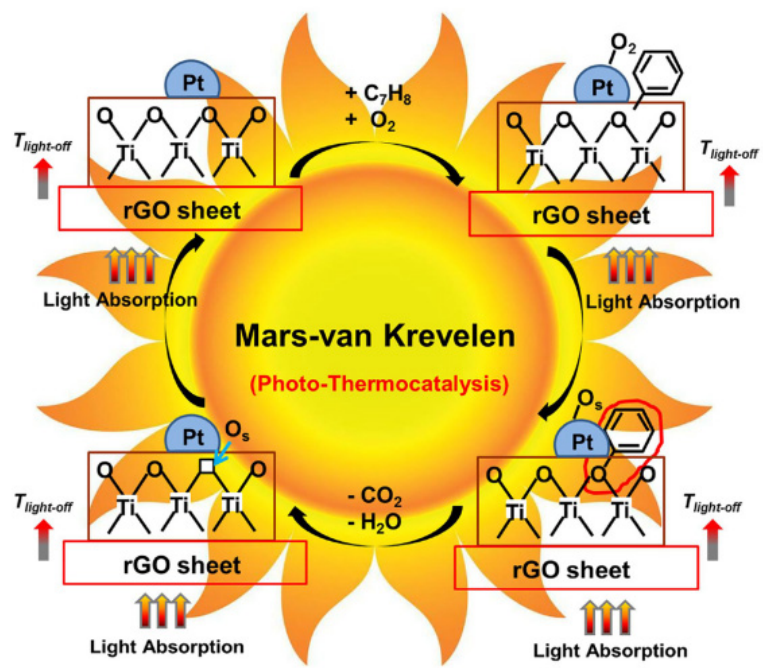

Fig. 13. Schematic of the photothermal synergistic catalytic degradation of VOCs over the Pt-rGO-TiO 2 catalyst. Reprinted with permission from Ref. [114]. Copyright (2018) Elsevier.

which enhanced the utilization efficiency of Pt.

Li et al. [103] reported a nanostructured Ce-ion-substituted OMS-2 (CM-120) catalyst for photothermocatalytic toluene oxidation. CM-120 demonstrated excellent photothermocatalytic performance under the full solar spectrum and vis-IR irradiation. Jia and coworkers [116] prepared $\mathrm{a} \mathrm{CeO}_{2} / \mathrm{LaMnO}_{3}$ catalyst that had a broad light absorption ability. The toluene removal efficiency was $89 \%$, and the photothermal conversion efficiency was $15.2 \%$ under IR irradiation. The high activity of the $\mathrm{CeO}_{2} / \mathrm{LaMnO}_{3}$ catalyst was due to the broad light absorption and high lattice oxygen mobility.

In a similar work, Jia and coworkers [117] reported $\mathrm{ACo}_{2} \mathrm{O}_{4}$ $(\mathrm{A}=\mathrm{Ni}, \mathrm{Cu}, \mathrm{Fe}$, and $\mathrm{Mn}$ ) catalysts for photothermocatalytic toluene oxidation. Fig. 14(a) shows the UV-vis diffuse reflectance spectroscopy (DRS) of the catalysts. Clearly, the $\mathrm{ACo}_{2} \mathrm{O}_{4}$ catalysts have strong light absorbing ability over the full solar spectrum, and $\mathrm{NiCo}_{2} \mathrm{O}_{4}$ shows the strongest light absorption. Thus, the $\mathrm{NiCo}_{2} \mathrm{O}_{4}$ catalyst demonstrated the highest photothermocatalytic activity (Fig. 14(b)). In this catalyst, the mobility of the active oxygen species was improved by light irradiation, thus enhancing the activity. Luo et al. [118] synthesized double-perovskite $\mathrm{LaAMnNiO}_{6}(\mathrm{~A}=\mathrm{La}, \mathrm{Pr}$, and $\mathrm{Sm})$ catalysts via (a)

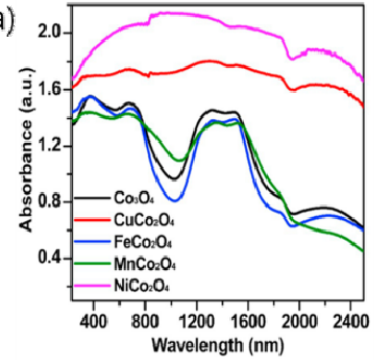

(b)

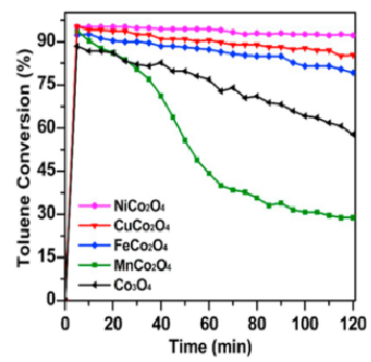

Fig. 14. (a) UV-vis diffuse reflectance spectroscopy spectra of the prepared samples; (b) Toluene conversion over the $\mathrm{ACo}_{2} \mathrm{O}_{4}$ catalysts under simulated sunlight irradiation. Reprinted with permission from Ref. [117]. Copyright (2019) Elsevier. 
the sol-gel method. Toluene was completely converted to $\mathrm{CO}_{2}$ and $\mathrm{H}_{2} \mathrm{O}$ over the $\mathrm{LaSmMnNiO}_{6}$ catalyst at $275{ }^{\circ} \mathrm{C}$. The $\mathrm{LaSmMnNiO}_{6}$ catalyst has a mesoporous structure with a large specific surface area, which results in high photothermocatalytic activity. Furthermore, the $\mathrm{LaSmMnNiO}_{6}$ catalyst follows the Mars-van Krevelen redox cycle mechanism, and the $\mathrm{Mn}^{4+} / \mathrm{Mn}^{3+}$ and $\mathrm{Ni}^{3+} / \mathrm{Ni}^{2+}$ pairs undergo strong valence transformation to promote lattice vibrations and produce more $\bullet \mathrm{O}^{2-}$ free radicals.

\subsection{Applications for the efficient removal of alcohols}

Ethanol, which is the most common monohydric alcohol, is a well-known VOCs. It is flammable, and a mixture of ethanol vapor and air forms an explosive mixture. Amal and coworkers reported $\mathrm{a} \mathrm{Au} / \mathrm{TiO}_{2}$ catalyst for the photothermocatalytic oxidation of ethanol (Fig. 15) [119]. Compared with $\mathrm{TiO}_{2}$, the $\mathrm{Au} / \mathrm{TiO}_{2}$ catalyst showed excellent photothermocatalytic activity under visible light and UV irradiation. Under visible light irradiation, the LSPR effect of Au contributes to the high activity. However, the photocatalysis and thermocatalysis of $\mathrm{TiO}_{2}$ and $\mathrm{Pt}$, respectively, synergistically improve the photothermocatalytic performance under UV irradiation. In a similar work, Datye et al. [120] prepared the $\mathrm{Pt} / \mathrm{TiO}_{2}$ catalyst for ethanol oxidation. The photothermocatalytic activity was much higher than the photocatalytic and thermocatalytic activities. Here, Pt and $\mathrm{TiO}_{2}$ serve as the thermocatalyst and photocatalyst, respectively. Furthermore, a Schottky barrier was produced at the interface of $\mathrm{Pt}$ and $\mathrm{TiO}_{2}$.

\subsection{Applications for the efficient removal of aldehydes}

Formaldehyde is a colorless and irritating gas, causing damage to the human eyes and nose. An aqueous solution of $40 \%$ formaldehyde is known as formalin and is used for sample preservation. Formaldehyde is a major component of indoor air pollution and is an important air pollutant affecting human health. It originates from furniture, children's clothing, cosmetics, pesticides, disinfectants, preservatives, printing inks, and many other sources. Thus, the removal of formaldehyde from the air is of significant interest.

Wang and coworkers prepared an $\mathrm{MnO}_{x}-\mathrm{CeO}_{2}$ catalyst for photothermal catalytic formaldehyde oxidation [121]. The formaldehyde removal efficiency was $90.4 \%$ after $3 \mathrm{~h}$ at $75^{\circ} \mathrm{C}$,
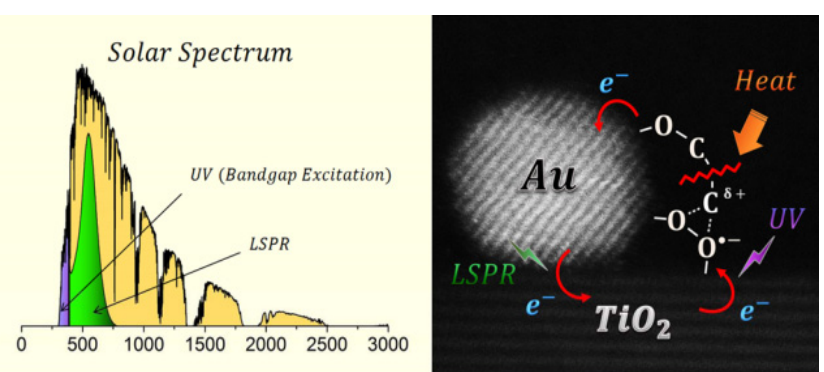

Fig. 15. Schematic of photothermal synergistic catalysis for ethanol oxidation over the $\mathrm{Au} / \mathrm{TiO}_{2}$ catalyst. Reprinted with permission from Ref. [119]. Copyright (2016) American Chemical Society. which was much higher than the photocatalytic and thermocatalytic efficiencies: $42.3 \%$ at $25{ }^{\circ} \mathrm{C}$ and $27.1 \%$ at $75{ }^{\circ} \mathrm{C}$, respectively. The high-valence metal ions and surface hydroxyl groups $(-\mathrm{OH})$ could have an important effect on the high photothermocatalytic performance. In a similar work, Wang et al. [122] reported the use of an amorphous $\mathrm{MnO}_{x}$-modified $\mathrm{Co}_{3} \mathrm{O}_{4}$ $\left(\mathrm{Co}_{x} \mathrm{Mn}_{y}\right)$ catalyst for formaldehyde oxidation. When the $\mathrm{Co} / \mathrm{Mn}$ molar ratio was $1: 1$, the $\mathrm{Co}_{1} \mathrm{Mn}_{1}$ catalyst showed the highest photothermocatalytic performance (Fig. 16(a)). As shown in Fig. 16(b), there was a photothermal synergistic catalytic effect in the $\mathrm{Co}_{1} \mathrm{Mn}_{1}$ catalyst. Possibly, the $\mathrm{MnO}_{x}$ doping enhanced the low-temperature thermocatalytic and photothermocatalytic performance. Furthermore, the strong interaction between $\mathrm{MnO}_{x}$ and $\mathrm{Co}_{3} \mathrm{O}_{4}$ could further increase the activity. Zhang and coworkers [123] constructed a graphene-doped $\mathrm{MnO}_{2}$ hybrid $\left(\mathrm{MnO}_{2}-\mathrm{G}\right)$ catalyst via a simple mechanochemical method and tested the photothermocatalytic performance for formaldehyde oxidation. The $\mathrm{MnO}_{2}-\mathrm{G}$ catalyst demonstrated good activity compared with those of $\mathrm{MnO}_{2}$ and graphene. Owing to the $\mathrm{MnO}_{2}-\mathrm{G}$ interface, the chargeability of $\mathrm{Mn}$ atoms was enhanced, which increased the electron density and facilitated the formation of superoxide radicals. Furthermore, the graphene enhanced light absorption.

Ji and coworkers reported the introduction of oxygen vacancies into BiOI nanosheets by a simple method [124]. When the amount of nitric acid was $8 \mathrm{~mL}$ (BiOI-8), the BiOI-8 catalyst exhibited the best photothermocatalytic performance under light irradiation. The BiOI-8 catalyst had many oxygen vacancy species and reduced recombination of $\mathrm{e}^{-}$and $\mathrm{h}^{+}$pairs, resulting in high photothermocatalytic activity.

Acetaldehyde is flammable and volatile, and a mixture of acetaldehyde vapor with air can be explosive. It also has an effect on human body. Thus, acetaldehyde removal hasaroused much attention. Nakano and coworkers [125] prepared a multi-functional $\mathrm{Pt}-\mathrm{TiO}_{2} / \mathrm{SiO}_{2}$ catalyst and tested its photothermocatalytic performance for acetaldehyde oxidation. The acetaldehyde removal efficiency was nearly $100 \%$. The $\mathrm{TiO}_{2}$ decomposed the acetaldehyde, $\mathrm{SiO}_{2}$ adsorbed the by-products, and $\mathrm{Pt}$ oxidized the by-products and coke precursors. Therefore, the $\mathrm{Pt}-\mathrm{TiO}_{2} / \mathrm{SiO}_{2}$ catalyst exhibited outstanding photothermocatalytic activity. Wang and coworkers [126] reported some cocatalysts for $\mathrm{TiO}_{2}$ for photothermocatalytic acetaldehyde oxidation under blue light irradiation. Using a hole-type $\mathrm{Cr}_{x} \mathrm{O}$ cocatalyst, $0.3 \mathrm{wt} \% \mathrm{Cr}_{x} \mathrm{O} / \mathrm{TiO}_{2}$ exhibited higher photothermocatalytic ac-
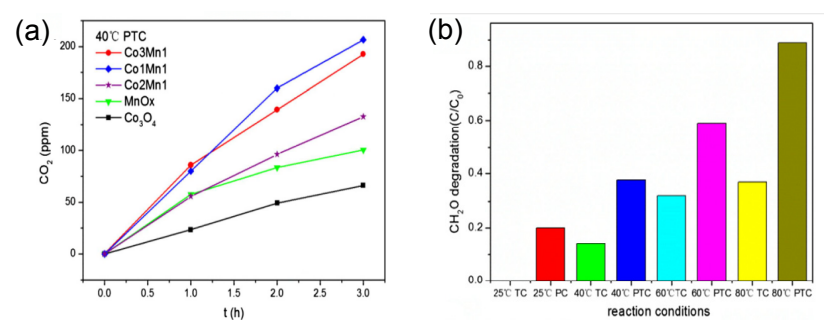

Fig. 16. (a) Change in $\mathrm{CO}_{2}$ concentration during the photothermocatalytic degradation of formaldehyde over $\mathrm{Co}_{x} \mathrm{Mn}_{y}$ catalysts at $40^{\circ} \mathrm{C}$; (b) Formaldehyde degradation rates under different reaction conditions over $\mathrm{Co}_{1} \mathrm{Mn}_{1}$ catalyst. Reprinted with permission from Ref. [122]. Copyright (2016) Elsevier. 
tivity than that of $3 \mathrm{wt} \% \mathrm{Cr}_{x} \mathrm{O} / \mathrm{TiO}_{2}$.

Zhang and coworkers [127] prepared oxygen vacancies on a $\mathrm{WO}_{3}$ catalyst by changing the hydrogen treatment temperature. With increase in the hydrogen treatment temperature, the concentration of oxygen vacancies was increased. When the hydrogen treatment temperature was $350{ }^{\circ} \mathrm{C}$, the concentration of oxygen vacancy was optimal, resulting in the highest photothermocatalytic activity. Fig. 17 shows a schematic of photothermal synergistic catalysis on $\mathrm{WO}_{3-x}$ catalysts.

\subsection{Applications for the efficient removal of ketones}

Acetone, which is the simplest saturated ketone, is a colorless transparent liquid with an aromatic odor and is highly volatile. Acetone is a well-known VOCs and is a significant health hazard to the human body. Thus, acetone removal has also aroused much attention. Li and coworkers [100] synthesized an OMS-2 nanorod catalyst for acetone oxidation, and acetone was completely oxidized to $\mathrm{CO}_{2}$ and $\mathrm{H}_{2} \mathrm{O}$ within 20 min under full solar spectrum irradiation. In a similar work, Li et al. [103] reported a nanostructured Ce-ion-substituted OMS-2 (CM-120) catalyst for photothermocatalytic acetone oxidation. The oxidation potential of acetone is lower than that of the benzene and toluene [128]. Therefore, the photothermocatalytic performance of acetone was much higher than those of benzene and toluene.

$\mathrm{Li}$ and coworkers [91] reported a $\mathrm{Pt}-\mathrm{CeO}_{2}-\mathrm{MM}$ catalyst for acetone oxidation. The acetone removal efficiency was approximately $95 \%$ within 20 min under full solar spectrum irradiation, which was much higher than that of $\mathrm{TiO}_{2}$ and $\mathrm{CeO}_{2}-\mathrm{MM}$. In a further study, Li and coworkers [129] prepared a nano-ZnO catalyst for acetone oxidation, and this catalyst also exhibited excellent activity.

\subsection{Applications for the efficient removal of other VOCs}

As one of the most important types of VOCs, non-methane hydrocarbons (NMHCs) play an extremely important role in atmospheric chemical processes, especially, because they form photochemical smog. In this section, we will discuss some NMHCs, excluding benzene, toluene, and xylene.

Ethylene is one of the world's largest output chemical products, and the ethylene industry is the core of the petrochemical industry. It is an important raw material for the manufacture of
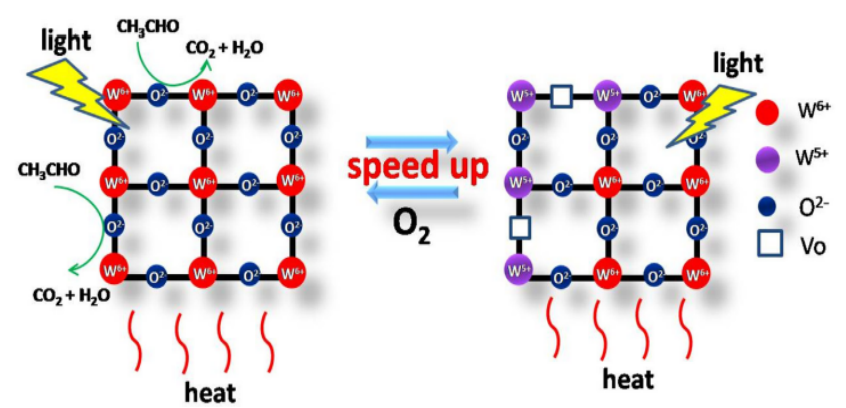

Fig. 17. Schematic of photothermal synergistic catalysis for ethanol oxidation on the $\mathrm{WO}_{3-x}$ catalyst. Reprinted with permission from Ref. [127]. Copyright (2017) Elsevier. plastics, synthetic ethanol, acetaldehyde, and synthetic fibers. However, it is also hazardous to the human body. $\mathrm{Hu}$ and coworkers [130] reported catalysts comprising metal nanoparticles (Pt, Pd, and $\mathrm{Au}$ ) supported on $\mathrm{TiO}_{2}$ /silica gel (TSO) and tested their photothermocatalytic performance for ethylene oxidation. The ethylene removal efficiency exceeded $94 \%$ at 90 ${ }^{\circ} \mathrm{C}$, which was much higher than that of the thermocatalytic process.

Wang and coworkers [131] used the electrochemical deposition method to deposit ultrathin mesoporous $\mathrm{Co}_{3} \mathrm{O}_{4}$ nanosheets onto a stainless-steel mesh (SS- $\left.\mathrm{Co}_{3} \mathrm{O}_{4}\right) . \mathrm{SS}^{-\mathrm{Co}_{3} \mathrm{O}_{4}}$ exhibited high photothermocatalytic performance for propylene and propane oxidation, which was much higher than that of P25. The ultrathin mesoporous structure offered more active sites, and the larger number of surface lattice oxygen species enhanced the photothermocatalytic performance. In a further study, Wang and coworkers [132] reported manganese oxides having pyrolusite $(1 \times 1)$, cryptomelane $(2 \times 2)$, and todorokite $(3 \times 3)$ square tunnels for photothermocatalytic propylene and propane oxidation under simulated sunlight and IR irradiation. Because of the tunnel structure and presence of a large number of $\mathrm{Mn}^{4+}$ sites, the $2 \times 2$ structure showed the highest activity.

Zhang and coworkers [133] reported a $\mathrm{Pt} / \mathrm{TiO}_{2}-\mathrm{WO}_{3}$ catalyst for the photothermocatalytic oxidation of propane at a high $\mathrm{O}_{2} / \mathrm{C}_{3} \mathrm{H}_{8}$ ratio. Compared to the thermocatalytic process, in the photothermocatalytic process, to achieve a $\mathrm{C}_{3} \mathrm{H}_{8}$ conversion of $70 \%$, the reaction temperature could be decreased from 324 to $90^{\circ} \mathrm{C}$ and the activation energy could be decreased from 130 to $11 \mathrm{~kJ} \mathrm{~mol}^{-1}$. Moreover, the reaction order with respect to oxygen was affected by the presence of light. On light exposure, the reaction order with respect to oxygen was 0.1 , but it was -1.4 in the dark. This result indicates that the $\mathrm{Pt} / \mathrm{TiO}_{2}-\mathrm{WO}_{3}$ catalyst could suppress oxygen poisoning in the Pt catalyst. In the dark, oxygen is preferentially is adsorbed on the active Pt sites, causing oxygen poisoning. However, in the light, the oxygen adsorbed on the Pt sites is activated, producing anionic superoxide, which can then react with other active species. These results demonstrate a new route for photothermal synergistic catalysis using semiconductor-loaded non-plasmonic metal catalysts.

An and coworkers [134] designed a $\mathrm{PtCu} / \mathrm{CeO}_{2}$ ordered porous catalyst via a deposition-precipitation method and tested the photothermocatalytic activity for $n$-pentane oxidation. The $n$-pentane removal efficiency was approximately $95 \%$ at $400{ }^{\circ} \mathrm{C}$ within 2 h. Fig. 18 shows a schematic of the photothermal synergistic catalysis on the $\mathrm{PtCu} / \mathrm{CeO}_{2}$ catalyst. The small amount of $\mathrm{PtCu}$ on $\mathrm{CeO}_{2}$ improved the light harvesting ability and enhanced the separation of the $\mathrm{e}^{-}$and $\mathrm{h}^{+}$pairs, resulting in high photothermocatalytic activity. Furthermore, there was a synergistic effect between the thermocatalytic and photocatalytic processes.

In a further work, $\mathrm{Ai}$ and coworkers [135] reported $\mathrm{ABO}_{3}(\mathrm{~A}$ $=\mathrm{La}, \mathrm{Ce}$, and $\mathrm{Sm}$; $\mathrm{B}=\mathrm{Cr}, \mathrm{Mn}, \mathrm{Fe}, \mathrm{Co}$, and $\mathrm{Ni}$ ) perovskites for the photothermocatalytic oxidation of styrene under visible light irradiation. Of the tested catalysts, $\mathrm{LaMnO}_{3}$ exhibited the best photothermocatalytic activity. The small crystal size and strong visible light absorption enhanced the photothermocatalytic 


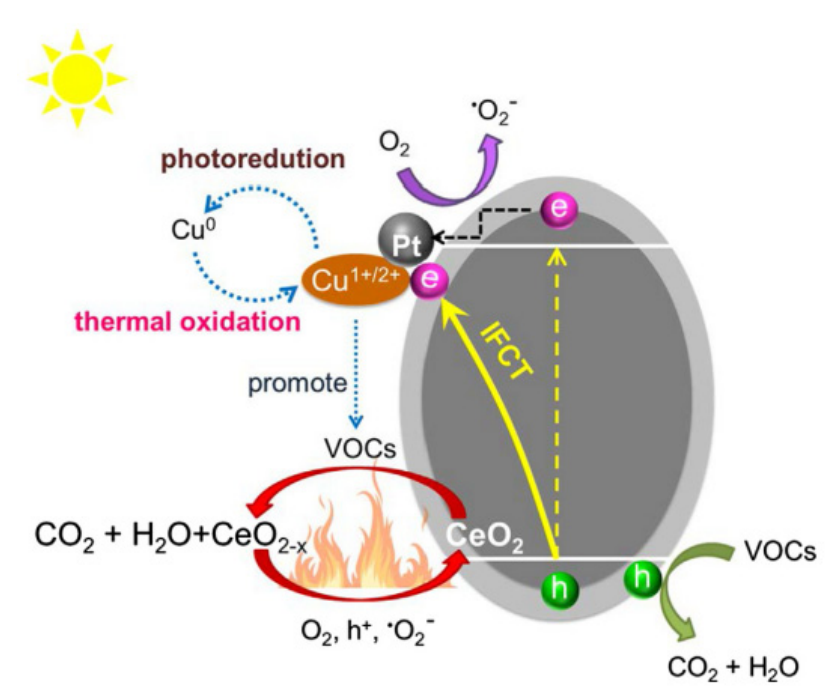

Fig. 18. Schematic of photothermal synergistic catalysis for VOCs oxidation on the $\mathrm{PtCu} / \mathrm{CeO}_{2}$ catalyst. Reprinted with permission from Ref. [134]. Copyright (2019) Elsevier.

performance.

\section{Applications of photothermal synergistic catalysis for the efficient removal of $\mathrm{CO}$}

\subsection{Applications for CO oxidation}

CO is a universal air pollutant with wide impact. Thus, CO oxidation is an important reaction, and thermocatalytic CO oxidation requires a relatively high temperature. However, photothermal synergistic catalysis can convert light into heat to drive $\mathrm{CO}$ oxidation, thus allowing the use of relatively low temperature. $\mathrm{Si}$ and coworkers reported a $\mathrm{Pd}-\mathrm{CeO}_{2}$ catalyst for photothermocatalytic CO oxidation under visible light irradiation [106]. The maximum light efficiency was $1 \%$ owing to the effective Pd-O-Ce interfaces. Liu et al. [136] synthesized core/shell $\mathrm{Ag} @ \mathrm{CeO}_{2}$ using a facile method; here, the core and shell were $\mathrm{Ag}$ and $\mathrm{CeO}_{2}$, respectively. Then, the prepared core/shell $\mathrm{Ag} @ \mathrm{CeO}_{2}$ was loaded onto $\mathrm{SiO}_{2}$ to fabricate a $\mathrm{Ag} @ \mathrm{CeO}_{2} / \mathrm{SiO}_{2}$ catalyst. Good photothermocatalytic performance for $\mathrm{CO}$ oxidation was obtained in a fixed-bed flow reactor. In particular, when the Ag NPs had a diameter of $12 \mathrm{~nm}$ and the reaction temperature was $250{ }^{\circ} \mathrm{C}$, $\mathrm{CO}$ was completely oxidized, demonstrating the high performance of the $\mathrm{Ag} @ \mathrm{CeO}_{2} / \mathrm{SiO}_{2}$ catalyst for $\mathrm{CO}$ oxidation.

$\mathrm{Xu}$ and coworkers prepared $\mathrm{CuO}$ hierarchical hollow particles/colloidosomes ( $\mathrm{CuO} \mathrm{HCs}$ ) using a Pickering emulsion method and explored their photothermocatalytic activity for CO oxidation in a sealed Pyrex cell [137]. At room temperature, the photothermal reaction rate was much higher than that of the thermocatalytic process at $240{ }^{\circ} \mathrm{C}$, indicating that the $\mathrm{CuO}$ HCs showed good photothermal activity. In addition, Li et al. [138] loaded $\mathrm{Fe}_{3} \mathrm{Si}$ onto $\mathrm{Co}_{3} \mathrm{O}_{4}$ nanorods to fabricate a $\mathrm{Fe}_{3} \mathrm{Si} / \mathrm{Co}_{3} \mathrm{O}_{4}$ nanocomposite catalyst and tested their photothermal activity for $\mathrm{CO}$ oxidation under weak solar irradiation. When the light intensity was $4.0 \mathrm{~kW} \mathrm{~cm}-2$, the CO conversion of the $\mathrm{Co}_{3} \mathrm{O}_{4}$ catalyst reached $90.2 \%$. However, when the light

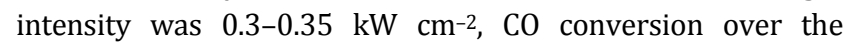
$\mathrm{Fe}_{3} \mathrm{Si} / \mathrm{Co}_{3} \mathrm{O}_{4}$ catalyst exceeded $95 \%$. Thus, weak solar irradiation can be used to drive $\mathrm{CO}$ oxidation using the $\mathrm{Fe} \mathrm{Si}_{3} / \mathrm{Co}_{3} \mathrm{O}_{4}$ nanocomposite catalyst. Li et al. [139] synthesized nanoflowers of an octahedral layered birnessite (OL-NF) catalyst that showed superior photothermal activity for $\mathrm{CO}$ oxidation under solar-light irradiation. The lattice oxygen in the OL-NF catalyst enhanced the activity.

Yang and coworkers reported a $\mathrm{Au} / \mathrm{TiO}_{2}-\mathrm{C}_{3} \mathrm{~N}_{4}$ catalyst for photothermal synergistic catalytic $\mathrm{CO}$ oxidation in the presence of $\mathrm{H}_{2}$ [140]. The photothermal activity of $\mathrm{Au} / \mathrm{TiO}_{2}-\mathrm{C}_{3} \mathrm{~N}_{4}$ was much higher than that of $\mathrm{Au} / \mathrm{TiO}_{2}$ and $\mathrm{Au} / \mathrm{C}_{3} \mathrm{~N}_{4}$. The reaction rates $(r \mathrm{CO})$ for $\mathrm{CO}$ oxidation over the $\mathrm{Au} / \mathrm{TiO}_{2}-\mathrm{C}_{3} \mathrm{~N}_{4}$ catalyst were 0.3877 and $0.2854 \mu \mathrm{mol} \mathrm{g} \mathrm{gat}^{-1} \mathrm{~s}^{-1}$ at 358 and $25^{\circ} \mathrm{C}$, respectively. Electron transfer in the $\mathrm{Au} / \mathrm{TiO}_{2}-\mathrm{C}_{3} \mathrm{~N}_{4}$ catalyst, as well as its Fermi level, are showed in Fig. 19. The Au NPs enhanced the electron transfer and CO activation owing to the LSPR effect. In particular, the electron density of the Au NPs was high, which suppressed $\mathrm{H}_{2}$ oxidation and improved $\mathrm{CO}_{2}$ production. Furthermore, the $\mathrm{TiO}_{2}$ and $\mathrm{C}_{3} \mathrm{~N}_{4}$ formed a nano-hetero-architecture that further enhanced the activity.

\subsection{Applications for CO hydrogenation}

\subsubsection{CO methanation}

CO methanation is an important process in proton exchange membrane fuel cells (PEMFCs) to eliminate the CO produced under the $\mathrm{H}_{2}$-rich conditions [141]. Nonetheless, this process requires a suitably high reaction temperature, and the water-gas shift reaction can occur. Fortunately, UV irradiation can be used to drive $\mathrm{CO}$ methanation. $\mathrm{Fu}$ and coworkers reported a $\mathrm{Ru} / \mathrm{TiO}_{2}$ catalyst for photothermocatalytic $\mathrm{CO}$ methanation on a flat-plate quartz cell under UV irradiation [142]. At reaction temperatures from 160 to $210{ }^{\circ} \mathrm{C}$, the photothermal activity was much higher than that of the thermocatalytic process, demonstrating that the activation energy was reduced and CO methanation was facilitated under UV irradiation. When the reaction temperature was $200{ }^{\circ} \mathrm{C}$, the $\mathrm{CO}$ was completely converted to $\mathrm{CH}_{4}$. Fig. 20 shows a schematic illustration of photo-

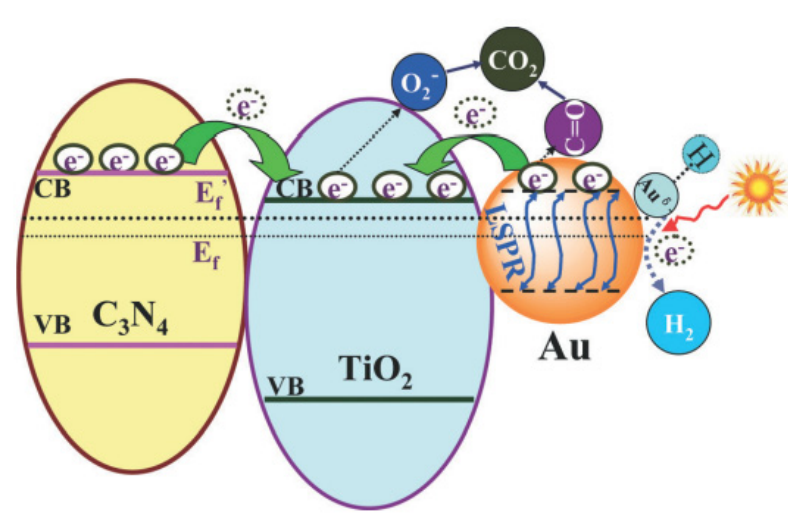

Fig. 19. Electron transfer and Fermi level of the $\mathrm{Au} / \mathrm{TiO}_{2}-\mathrm{C}_{3} \mathrm{~N}_{4}$ catalyst under visible light irradiation. Reprinted with permission from Ref. [140]. Copyright (2016) Royal Society of Chemistry. 


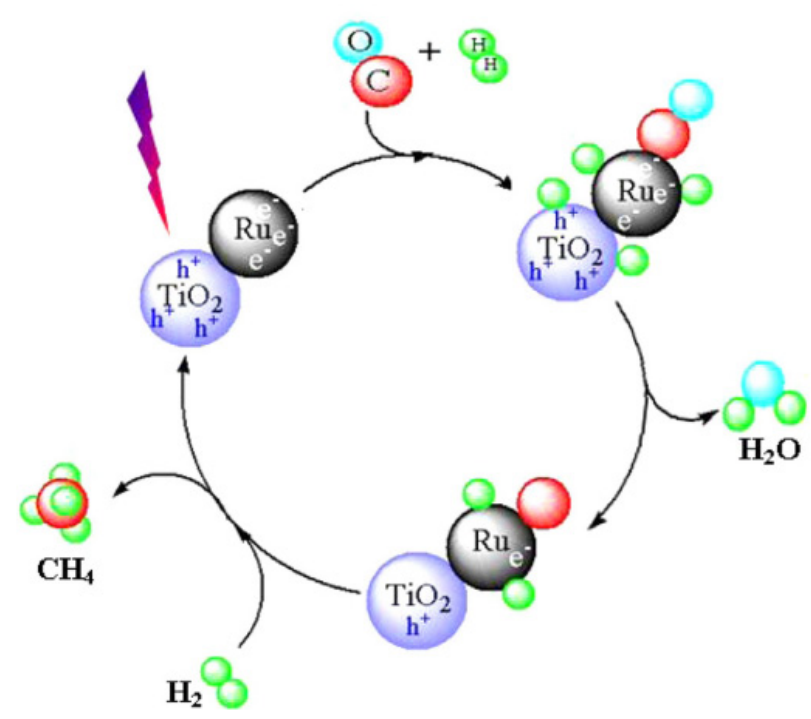

Fig. 20. Schematic of photothermal synergistic catalysis for CO methanation on $\mathrm{Ru} / \mathrm{TiO}_{2}$ catalyst under the UV light irradiation. Reprinted with permission from Ref. [142]. Copyright (2014) Elsevier.

thermal synergistic catalytic $\mathrm{CO}$ methanation over the $\mathrm{Ru} / \mathrm{TiO}_{2}$ catalyst. The surface electron density at the Ru sites was enhanced, thus improving the CO methanation activity. In a similar study, $\mathrm{Fu}$ et al. [143] prepared the $\mathrm{Ni} / \mathrm{TiO}_{2}$ catalyst for the $\mathrm{CO}$ methanation to $\mathrm{CH}_{4}$.

\subsubsection{Fischer-Tropsch synthesis}

$\mathrm{CO}$ and $\mathrm{H}_{2}$ (syngas) can be used for the Fischer-Tropsch synthesis (FTS) reaction to generate liquid fuels and chemicals such as light olefins, methanol, and aromatics [144]. However, FTS also requires a relatively high reaction temperature. Fortunately, the use of photothermal synergistic catalysis allows lower reaction temperature to be used. Guo and coworkers synthesized a $\mathrm{Ru}$ /graphene catalyst, where the diameter and length of the worm-like $\mathrm{Ru}$ particles were approximately 2.2 and $10 \mathrm{~nm}$, respectively [145]. With increasing light intensity, the photothermocatalytic activity for $\mathrm{CO}$ hydrogenation gradually increased. At a light intensity of $0.5 \mathrm{~W} \mathrm{~cm}^{-2}$ and reaction temperature of $150{ }^{\circ} \mathrm{C}$, the catalytic performance was the highest: 14.4 molco $_{\mathrm{Col}} \mathrm{Ru}^{-1} \mathrm{~h}^{-1}$. Moreover, with decreasing irradiation wavelength, the catalytic performance was also enhanced. A schematic of photothermal synergistic catalytic FTS on the $\mathrm{Ru}$ /graphene catalyst is shown in Fig. 21.

Zhang and coworkers [146] reported a Ni-loaded MnO support for photothermal synergistic catalytic FTS to light olefins under UV-vis irradiation. When the reduction temperature was $500{ }^{\circ} \mathrm{C}$, the prepared catalyst had high activity, and the percentage conversion of $\mathrm{CO}$ was $14.9 \%$ and the olefin selectivity was 33\%. Furthermore, structural characterization confirmed that there were some $\mathrm{Ni}^{\delta}$ sites on the MnO support, which facilitated the $\mathrm{C}-\mathrm{C}$ coupling reaction to produce olefins. In a similar work, Su et al. [147] synthesized an Fe-loaded mesostructured titania $\left(\mathrm{mTiO}_{2}\right)$ catalyst by an impregnation method and tested its photothermocatalytic activity for Fischer-Tropsch synthesis.

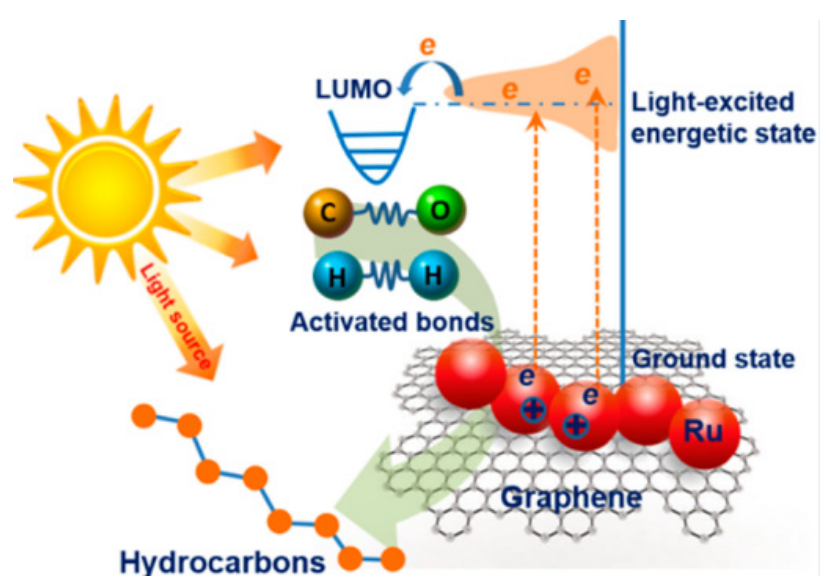

Fig. 21. Schematic of photothermal synergistic catalytic FTS on the $\mathrm{Ru}$ /graphene catalyst. Reprinted with permission from Ref. [145]. Copyright (2015) American Chemical Society.

\section{Mechanism of photothermal synergistic catalysis}

\subsection{Surface plasmon effect}

Nowadays, the surface plasmon effect is an important mechanism for photothermal synergistic catalysis. There is a surface plasmon effect on most metal-semiconductor catalysts. Under light irradiation, the surface plasmon effect of an noble metal produces some hot electrons, thus enhancing the thermocatalytic activity [58]. Moreover, the noble metal can capture the photogenerated electrons to improve the carrier separation efficiency, thus improving the photocatalytic activity [58]. Therefore, the surface plasmon effect can be used to explain the photothermocatalytic mechanism. Si et al. [106] reported a $\mathrm{Pd} / \mathrm{CeO}_{2}$ catalyst for photothermal synergistic catalytic toluene and CO oxidation under visible light irradiation. In this catalyst, there are strong electron interactions between Pd and $\mathrm{CeO}_{2}$. The hot electrons generated by the surface plasmon

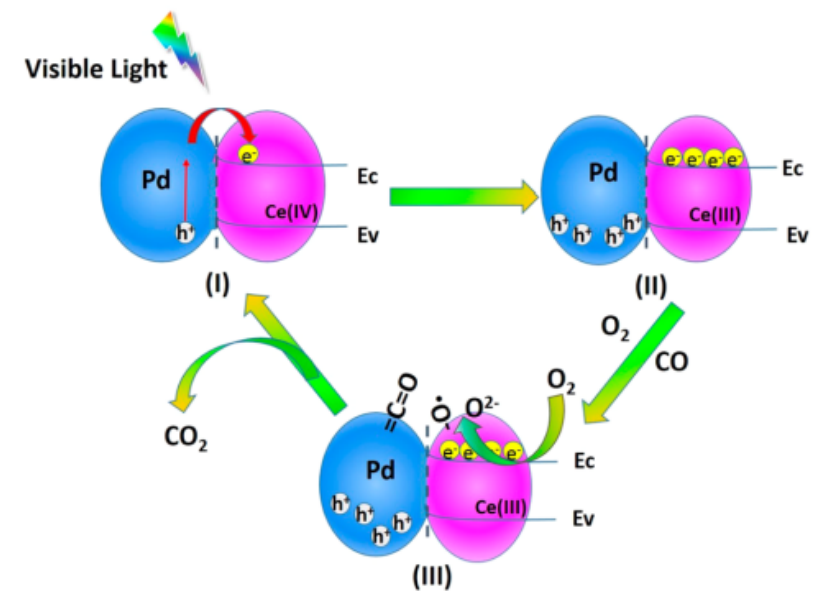

Fig. 22. Reaction route for photothermal synergistic catalytic $\mathrm{CO}$ oxidation over the $\mathrm{Pd} / \mathrm{CeO}_{2}$ catalyst under visible light illumination. Reprinted with permission from Ref. [106]. Copyright (2016) American Chemical Society. 
effect of Pd are transferred to the conduction band of $\mathrm{CeO}_{2}$, facilitating the activation of oxygen at the interface of $\mathrm{Pd}$ and $\mathrm{CeO}_{2}$ and enhancing the dissociation of adsorbed oxygen. Therefore, the surface plasmon effect contributes to toluene and $\mathrm{CO}$ oxidation, thus improving the photothermal activity of the $\mathrm{Pd} / \mathrm{CeO}_{2}$ catalyst. Fig. 22 shows the reaction route on the $\mathrm{Pd} / \mathrm{CeO}_{2}$ catalyst for photothermal synergistic catalytic $\mathrm{CO}$ oxidation. Under visible light illumination, hot electrons are produced at the interface of $\mathrm{Pd}$ and $\mathrm{CeO}_{2}$ to overcome the Schottky barrier. Then, they are transferred to the conduction band of $\mathrm{CeO}_{2}$ to reduce $\mathrm{Ce}(\mathrm{IV})$. Furthermore, the $\mathrm{O}^{2-}$ species oxidize $\mathrm{CO}$ to $\mathrm{CO}_{2}$.

In a similar work, Amal and coworkers reported a $\mathrm{Au} / \mathrm{TiO}_{2}$ catalyst for photothermal synergistic catalytic ethanol oxidation [119]. Under visible light irradiation, hot electrons generated by the surface plasmon effect of $\mathrm{Au}$ are transferred to $\mathrm{TiO}_{2}$, thus enhancing the photothermal activity. Therefore, the hot electrons produced by the surface plasmon effect of a noble metal can improve the photothermal performance, and the surface plasmon effect can be used to explain the mechanism of photothermal synergistic catalysis.

\subsection{Mars-van Krevelen redox cycle theory}

In addition to the surface plasmon effect, Mars-van Krevelen redox cycle theory, which is an important mechanism for surface catalytic reactions, is often used to explain photothermal synergistic catalysis. This mechanism, is mainly applied to transition metal oxides. The Mars-van Krevelen redox cycle involves the redox processes between the reactant and catalyst lattice oxygen. There are two steps: In the first step, an oxygen vacancy is produced and then reduced by the reaction between the reactant and catalyst. In the second step, the oxygen absorbed by the catalyst replenishes the oxygen vacancies for reoxidation and regeneration. Li et al. [70] reported anatase $\mathrm{TiO}_{2}$ nanosheets with a main $\{001\}$ facet for the photothermal synergistic catalysis of gas-phase benzene. In the benzene oxidation process, the $\mathrm{TiO}_{2}$ is converted $\mathrm{TiO}_{2-x}$ owing to the lattice oxygen, and benzene is oxidized to $\mathrm{CO}_{2}$ and $\mathrm{H}_{2} \mathrm{O}$; then, the $\mathrm{TiO}_{2-x}$ is reoxidized to $\mathrm{TiO}_{2}$. Thus, the Mars-van Krevelen redox cycle between $\mathrm{TiO}_{2}$ and $\mathrm{TiO}_{2-x}$ enhances the photothermocatalytic activity. $\mathrm{Li}$ and coworkers reported $\mathrm{Co}_{3} \mathrm{O}_{4}$ mesoporous nanorods $\left(\mathrm{Co}_{3} \mathrm{O}_{4}\right.$-MNR) with $\mathrm{Co}^{2+}$ vacancy defects for photothermal synergistic catalytic benzene oxidation [86]. The $\mathrm{Co}_{3} \mathrm{O}_{4}$-MNR catalyst showed high photothermocatalytic activity owing to the surface lattice oxygen in $\mathrm{Co}_{3} \mathrm{O}_{4}$ formed by the Mars-van Krevelen mechanism. Therefore, Mars-van Krevelen redox cycle theory well explains the photothermal synergistic catalytic mechanism.

\section{Conclusions and perspectives}

In summary, in this minireview, we have discussed the design and fabrication of nanomaterials for the photothermal synergistic catalytic removal of VOCs and CO. Using rational design, efficient photothermal catalysts have been prepared. Further, the use of photothermal synergistic catalysis can sig- nificantly improve the shortcomings of separate photocatalytic and thermocatalytic processes. The examples given in this review show that photothermocatalytic performance is higher than those of photocatalytic and thermocatalytic processes.

Thus, photothermal catalysis is a new method in catalysis and has a bright future. To date, it has been applied to many fields, including VOCs removal, renewable energy production, and organic synthesis. However, this technology is still immature, and there are many scientific and technological problems to be solved. Therefore, photothermal synergistic catalysis is far from practical industrial application. Currently, photothermal catalysts are developed by designing and optimizing photocatalytic or thermocatalytic processes, and the energy efficiency of photothermal synergistic catalysis for VOCs removal and CO remains low. To take full advantage of the full solar energy spectrum, catalysts having visible light and even the IR responses should be developed. In addition, the basic mechanism of photothermal synergistic catalysis is mainly explained based on the surface plasmon effect and Mars-van Krevelen redox cycle theory. However, the mechanism should be further elaborated using in situ characterization and quantitative calculations. We hope that this minireview will stimulate new insights and provide directions for future research into the efficient removal of VOCs and CO, which will be beneficial to society.

\section{Conflicts of interest}

There are no conflicts to declare.

\section{References}

[1] K. Vikrant, K. H. Kim, W. X. Peng, S. B. Ge, Y. S. Ok, Chem. Eng. J., 2020, 387, 123943.

[2] W. X. Zou, B. Gao, Y. S. Ok, L. Dong, Chemosphere, 2019, 218, 845-859.

[3] Z. Shayegan, F. Haghighat, C. S. Lee, Chem. Eng. J., 2019, 357, 533-546.

[4] Y. Lyu, C. T. Li, X. Y. Du, Y. C. Zhu, Y. D. Zhang, S. H. Li, Fuel, 2020, $262,116610$.

[5] J. Lee, J. Lee, S. H. Lim, J. Hazard. Mater., 2020, 392, 122145.

[6] C. Q. Li, Z. M. Sun, A. K. Song, X. B. Dong, S. L. Zheng, D. D. Dionysiou, Appl. Catal. B, 2018, 236, 76-87.

[7] D. Wang, L. Nie, X. Shao, H. B. Yu, Sci. Total Environ., 2017, 603-604, 57-65.

[8] P. Zhao,Y. H. Cheng, C. C. Lin, Y. L. Cheng, Environ. Sci. Pollut. Res., 2016, 23, 3799-3808.

[9] F. J. Lu, S. H. Li, B. X. Shen, J. W. Zhang, L. J. Liu, X. Q. Shen, R. X. Zhao, J. Hazard. Mater., 2020, 384, 121428.

[10] T. Guo, X. S. Li, J. Q. Li, Z. Peng, L. Xu, J. G. Dong, P. Cheng, Z. Zhou, Chemosphere, 2018, 194, 139-146.

[11] Z. X. Zhang, Z. Jiang, W. F. Shangguan, Catal. Today, 2016, 264, 270-278.

[12] V. T. D. Hien, C. Lin, V. C. Thanh, N. T. K. Oanh, B. X. Thanh, C. E. Weng, C. S. Yuan, E. R. Rene, J. Environ. Manage., 2019, 247, 401-412.

[13] S. H. Zhang, J. P. You, C. Kennes, Z. W. Cheng, J. X. Ye, D. Z. Chen, J. M. Chen, L. D. Wang, Chem. Eng. J., 2018, 334, 2625-2637.

[14] Y. J. Shu, M. He, J. Ji, H. B. Huang, S. W. Liu, D. Y. C. Leung, J. Hazard. 


\section{Graphical Abstract}

Chin. J. Catal., 2021, 42: 1078-1095 doi: 10.1016/S1872-2067(20)63721-4

\section{Recent advances in VOCs and CO removal via photothermal synergistic catalysis}

Longfu Wei, Changlin Yu *, Kai Yang, Qizhe Fan, Hongbing Ji *

Guangdong University of Petrochemical Technology; Jiangxi University of Science and Technology

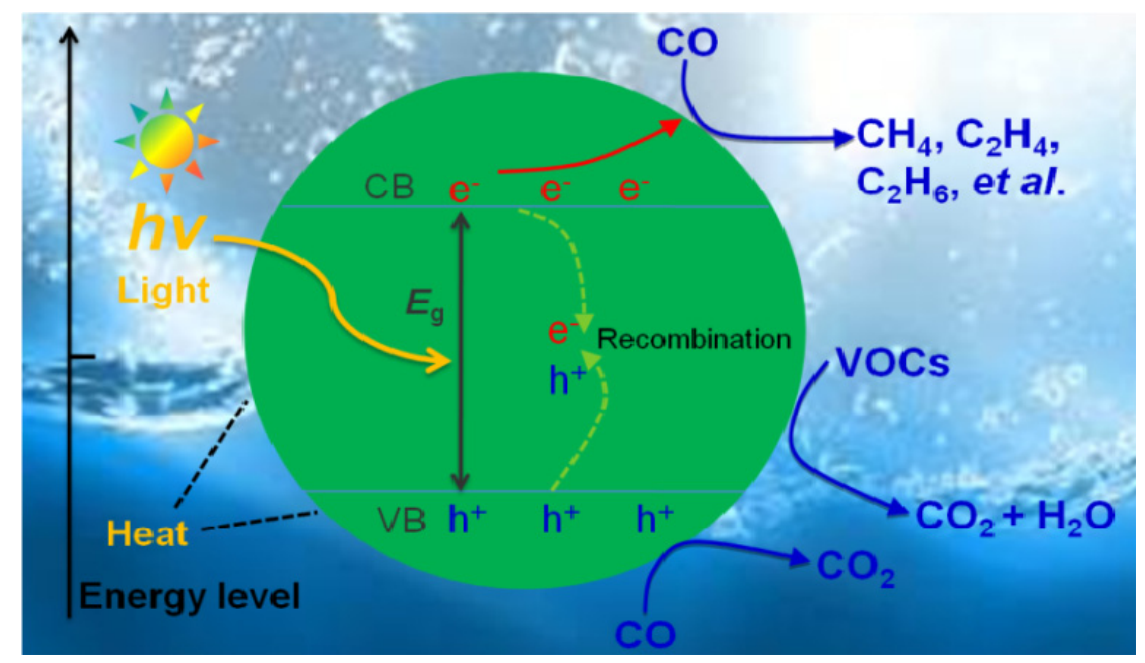

This review summarizes the design and fabrication of nanomaterials and their recent progresses with the photothermal synergistic catalysis for efficient removal of VOCs and CO. Furthermore, the typical reactor and mechanism are also analyzed.

Mater., 2019, 364, 770-779.

[15] R. Gao, D. P. Yan, Chem. Commun., 2017, 53, 5408-5411.

[16] V. K. Tomera, S. Duhan, J. Mater. Chem. A, 2016, 4, 1033-1043.

[17] Y. J. Shu, Y. Xu, H. B. Huang, J. Ji, S. M. Liang, M .Y. Wu, D. Y. C. Leung, Chemosphere, 2018, 208, 550-558.

[18] A. Fujishima, K. Honda, Nature, 1972, 238, 37-38.

[19] X. Li, C. Y. Liu, D. Y. Wu, J. Z. Li, P. W. Huo, H. Q. Wang, Chin. J. Catal., 2019, 40, 928-939.

[20] L. F. Wei, C. L. Yu, Q. H. Zhang, H. Liu, Y. Wang, J. Mater. Chem. A, 2018, 6, 22411-22436.

[21] S. J. Xie, Y. Wang, Q. H. Zhang, W. P. Deng, Y. Wang, Chem. Commun., 2015, 51, 3430-3433.

[22] Q. G. Zhai, S. J. Xie, W. Q. Fan, Q. H. Zhang, Y. Wang, W. P. Deng, Y. Wang, Angew. Chem. Int. Ed., 2013, 52, 5776-5779.

[23] S. B. Wang, B. Y. Guan, X. W. D. Lou, J. Am. Chem. Soc., 2018, 140, 5037-5040.

[24] R. Long, Y. Li, Y. Liu, S. M. Chen, X. S. Zheng, C. Gao, C. H. He, N. S. Chen, Z. M. Qi, L. Song, J. Jiang, J. F. Zhu, Y. J. Xiong, J. Am. Chem. Soc., 2017, 139, 4486-4492.

[25] Y. X. Pan, Y. You, S. Xin, Y .T. Li, G. T. Fu, Z. M. Cui, Y. L. Men, F. F. Cao, S. H. Yu, J. B. Goodenough, J. Am. Chem. Soc., 2017, 139, 4123-4129.

[26] X. Li, J. G. Yu, M. Jaronie, X. B. Chen, Chem. Rev., 2019, 119, 3962-4179.

[27] Z. Li, Y. Qi, W. Y. Wang, D. Li, Z. Li, Y. A. Xiao, G. Y. Han, J. R. Shen, C. Li, Chin. J. Catal., 2019, 40, 486-494.

[28] L .C. Wang, S. Cao, K. Guo, Z. J. Wu, Z. Ma, L. Y. Piao, Chin. J. Catal., 2019, 40, 470-475.

[29] X. M. Xiang, L. J. Chou, X. H. Li, Chin. J. Catal., 2018, 39, 407-412.

[30] W. J. Zhang, Y. Hu, C. Z. Yan, D. C. Hong, R. P. Chen, X. L. Xue, S. Y.
Yang, Y. X. Tian, Z. X. Tie, Z. Jin, Nanoscale, 2019, 11, 9053-9060.

[31] J. X. Xu, Y. H. Qi, C. Wang, L. Wang, Appl. Catal. B, 2019, 241, 178-186.

[32] S. S. Chen, T. Hisatomi, G. J. Ma, Z. Wang, Z. H. Pan, T. Takata, K. Domen, Chin. J. Catal., 2019, 40, 1668-1672.

[33] J. Yuan, J. Wen, Y. Zhong, X. Li, Y. Fang, S. Zhang, W. Liu, J. Mater. Chem. A, 2015, 3, 18244-18255.

[34] R. B. Wei, Z. L. Huang, G. H. Gu, Z. Wang, L. X. Zeng, Y. B. Chen, Z. Q. Liu, Appl. Catal. B, 2018, 231, 101-107.

[35] Y. J. Xiao, X. Y. Guo, J. X. Liu, L. F. Liu, F. X. Zhang, C. Li, Chin. J. Catal., 2019, 40, 1339-1344.

[36] N. C. Zheng, T. Ouyang, Y. B. Chen, Z. Wang, D. Y. Chen, Z. Q. Liu, Catal. Sci. Technol., 2019, 9, 1357-1364.

[37] Y. J. Wang, Y. Li, S. W. Cao, J. G. Yu, Chin. J. Catal., 2019, 40, 867-874

[38] H. Wang, X. M. Wang, R. T. Chen, H. F. Zhang, X. L. Wang, J. H. Wang, J. Zhang, L. C. Mu, K. F. Wu, F. T. Fan, X. Zong, C. Li, ACS Energy Lett., 2019, 4, 40-47.

[39] X. M. Wang, W. G. Ma, Z. Q. Xu, H. Wang, W. J. Fan, X. Zong, C. Li, Nano Energy, 2018, 48, 500-509.

[40] X. Zong, H. J. Yan, G. P. Wu, G. J. Ma, F. Y. Wen, L. Wang, C. Li, J. Am. Chem. Soc., 2008, 130, 7176-7177.

[41] P. Chen, H. Wang, H. J. Liu, Z. L. Ni, J. Y. Li, Y. Zhou, F. Dong, Appl. Catal. B, 2019, 242, 19-30.

[42] X. J. Zou, C. Y. Yuan, Y. Y. Dong, H. Ge, J. Ke, Y. B. Cui, Chem. Eng. J., 2020, 379, 122380.

[43] Y. X. Ji, A. Mattsson, G. A. Niklasson, C. G. Granqvist, L. Österlund, Joule, 2019, 3, 2457-2471.

[44] R. Y. Zhang, T. Ran, Y. H. Cao, L. Q. Ye, F. Dong, Q. Zhang, L. Z. Yuan, Y. Zhou, Chem. Eng. J., 2020, 382, 123029. 
[45] A. H. Mamaghani, F. Haghighat, C. S. Lee, J. Photochem. Photobiol. A, 2019, 378, 156-170.

[46] C. L. Yu, H. B. He, X. Q. Liu, J. L. Zeng, Z. Liu, Chin. J. Catal., 2019, 40, 1212-1221.

[47] K. Yang, X. X. Li, D. B. Zeng, F. Y. Chen, C. L. Yu, K. L. Zhang, W. Y. Huang, Chin. J. Catal., 2019, 40, 796-818.

[48] J. F. Li, C. Y. Zhong, J. R. Huang, Y. B. Chen, Z. Wang, Z. Q. Liu, J. Colloid Interface Sci., 2019, 553, 758-767.

[49] S. He, K. Xiao, X. Z. Chen, T. Li, T. Ouyang, Z. Wang, M. L. Guo, Z. Q. Liu, J. Colloid Interface Sci., 2019, 557, 644-654.

[50] C. L. Yu, D. B. Zeng, Q. Z. Fan, K. Yang, J. L. Zeng, L. F. Wei, J. H. Yi, H. B. Ji, Environ. Sci.: Nano, 2020, 7, 286-303.

[51] D. B. Zeng, K. Yang, C. L. Yu, F. Y. Chen, X. X. Li, Z. Wu, H. Liu, Appl. Catal. B, 2018, 237, 449-463.

[52] M. R. Shariati, A. Samadi-Maybodi, A. H. Colagar, J. Mater. Chem. A, 2018, 6, 20433-20443.

[53] Z. B. Xiang, Y. Wang, P. Ju, Y. Long, D. Zhang, J. Alloys Compd., 2017, 721, 622-627.

[54] J. T. Zhang, X. Liu, X. Y. Wang, L. L. Mu, M. M. Yuan, B. K. Liu, H. Z. Shi, J. Hazard. Mater., 2018, 359, 1-8.

[55] Y. B. Jin, J. T. Long, X. Ma, T. H. Zhou, Z. Z. Zhang, H. X. Lin, J. L. Long, X. X. Wang, Appl. Catal. B, 2019, 256, 117873.

[56] S. M. Lam, J. A. Quek, J. C. Sin, J. Photochem. Photobiol. A, 2018, 353, 171-184.

[57] J. Ji, Y. Xu, H. B. Huang, M. He, S. L. Liu, G. Y. Liu, R. J. Xie, Q. Y. Feng, Y. J. Shu, Y. J. Zhan, R. M. Fang, X. G. Ye, D. Y. C. Leung, Chem. Eng. J., 2017, 327, 490-499.

[58] Z. B. Rui, X. Q. Yang, J. F. Chen, H. B. Ji, CIESC Journal, 2018, 69, 4947-4958.

[59] D. S. Selishchev, N. S. Kolobov, A. A. Pershin, D. V. Kozlov, Appl. Catal. B, 2017, 200, 503-513.

[60] W. Han, J. G. Deng, S. H. Xie, H. G. Yang, H. X. Dai, C. T. Au, Ind. Eng. Chem. Res., 2014, 53, 3486-3494.

[61] S. Zhao, K. Z. Li, S. Jiang, J. H. Li, Appl. Catal. B, 2016, 181, 236-248.

[62] K. Yang, Y. J. Zhang, C. Meng, F. F. Cao, X. Chen, X. Z. Fu, D. W. Dai, C. L. Yu, Appl. Surf. Sci., 2017, 391, 635-644.

[63] M. Zeng, Y. Z. Li, M. Y. Mao, J. L. Bai, L. Ren, X. J. Zhao, ACS Catal., 2015, 5, 3278-3286.

[64] J. Chen, Z. S. Chen, X. Y. Zhang, X. F. Li, L. H. Yu, D. Z. Li, Appl. Catal. $B, 2017,210,379-385$.

[65] M. B. H. Abadia, H. Shirkhanloob, J. Rakhtshahc, Arab. J. Chem., 2020, 13, 1741-1751.

[66] H. X. Wen, L. Y. Yuan, C. X. Wei, Y. Zhao, Y. Qian, P. Ma, S. M. Ding, X. Yang, X. L. Wang, Environ. Toxicol. Phar., 2016, 45, 265-273.

[67] K. Li, B. Peng, T. Peng, ACS Catal., 2016, 6, 7485-7527.

[68] W. Yuan, L. Cheng, Y. An, S. Lv, H. Wu, X. Fan, Y. Zhang, X. Guo, J. Tang, Adv. Sci., 2018, 5, 1700870.

[69] M. Ge, C. Cao, J. Huang, S. Li, Z. Chen, K. Zhang, S. S. Al-Deyabd, Y. Lai, J. Mater. Chem. A, 2016, 4, 6772-6801.

[70] L. Ren, M. Y. Mao, Y. Z. Li, L. Lan, Z. Zhang, X. J. Zhao, Appl. Catal. B, 2016, 198, 303-310.

[71] X. X. Wang, D. W. Zeng, C. S. Xie, Mater. Lett., 2015, 139, 336-339.

[72] Y. Z. Li, J. C. Huang, T. Peng, J. Xu, X. J. Zhao, ChemCatChem, 2010, 2, 1082-1087.

[73] X. Z. Fu, W. A. Zeltner, M. A. Anderson, Appl. Catal. B, 1995, 6, 209-224.

[74] G. P. Wang, W. Qiu, C. J. Ren, J. J. Chai, W. Dong, Y. Q. Chen, M. C. Gong, Chin. J. Catal., 2009, 30, 913-918.

[75] C. J. Ren, X. J. Liu, G. P. Wang, S. Miao, Y. Q. Chen, J. Mol. Catal. A, 2012, 358, 31-37.
[76] J. T. Hou, L. L. Liu, Y. Z. Li, M. Y. Mao, H. Q. Lv, X. J. Zhao, Environ. Sci. Technol., 2013, 47, 13730-13736.

[77] Y. Yang, Y. Z. Li, M. Y. Mao, M. Zeng, X. J. Zhao, ACS Appl. Mater. Interfaces, 2017, 9, 2350-2357.

[78] C. Gao, Q. Q. Meng, K. Zhao, H. J. Yin, D. W. Wang, J. Guo, S. L. Zhao, L. Chang, M. He, Q. X. Li, H. J. Zhao, X. J. Huang, Y. Gao, Z. Y. Tang, Adv. Mater., 2016, 28, 6485-6490.

[79] L. Wang, J. W. Wan, Y. S. Zhao, N. L. Yang, D. Wang, J. Am. Chem. Soc., 2019, 141, 2238-2241.

[80] W. Y. Chen, B. Han, C. Tian, X. M. Liu, S. J. Liang, H. Deng, Z. Lin, Appl. Catal. B, 2019, 244, 996-1003.

[81] A. Gasparotto, D. Barreca, D. Bekermann, A. Devi, R. A. Fischer, P. Fornasiero, V. Gombac, O. I. Lebedev, C. Maccato, T. Montini, G. V. Tendeloo, E. Tondello, J. Am. Chem. Soc., 2011, 133, 19362-19365.

[82] J. Liu, J. Ke, Y. Li, B. J. Liu, L. D. Wang, H. N. Xiao, S. B. Wang, Appl. Catal. B, 2018, 236, 396-403.

[83] X. W. Xie, Y. Li, Z. Q. Liu, M. Haruta, W. J. Shen, Nature, 2009, 458, 746-749.

[84] L. H. Hu, Q. Peng, Y. D. Li, J. Am. Chem. Soc., 2008, 130, 16136-16137.

[85] X. Y. Wang, Y. Liu, T. H. Zhang, Y. J. Luo, Z. X. Lan, K. Zhang, J. C. Zuo, L. L. Jiang, R. H. Wang, ACS Catal., 2017, 7, 1626-1636.

[86] L. Lan, Z. K. Shi, Q. Zhang, Y. Z. Li, Y. Yang, S. W. Wu, X. J. Zhao, J. Mater. Chem. A, 2018, 6, 7194-7205.

[87] C. Chen, Y. Z. Li, Y. Yang, Q. Zhang, J. C. Wu, X. Xie, Z. K. Shi, X. J. Zhao, Environ. Sci.: Nano, 2019, 6, 1233-1245.

[88] D. Kumar, A. Lee, T. Lee, M. Lim, D. K. Lim, Nano Lett., 2016, 16, 1760-1767.

[89] B. H. Wu, D. Y. Liu, S. Mubeen, T. T. Chuong, M. Moskovits, G. D. Stucky, J. Am. Chem. Soc., 2016, 138, 1114-1117.

[90] J.S. Duchene, B. C. Sweeny, A. C. Johnston-Peck, D. Su, E. A. Stach, W. D. Wei, Angew. Chem. Int. Ed., 2014, 53, 7887-7891.

[91] M. Y. Mao, Y. Z. Li, H. Q. Lv, J. T. Hou, M. Zeng, L. Ren, H. Huang, X. J. Zhao, Environ. Sci.: Nano, 2017, 4, 373-384.

[92] J. L. Fang, Z. S. Chen, Q. Zheng, D. Z. Li, Catal. Sci. Technol., 2017, 7, 3303-3311.

[93] H. Huang, D. Li, Q. Lin, W. Zhang, Y. Shao, Y. Chen, M. Sun, X. Fu, Environ. Sci. Technol., 2009, 43, 4164.

[94] J. L. Fang, D. Z. Li, Y. Shao, J. H. Hu, J. Mater. Chem. A, 2016, 4, 14213-14221.

[95] C. J. Ren, T. Zou, G. Q. Chen, Y. Q. Chen, M. C. Gong, Chin. J. Catal., 2006, 27, 1048-1050.

[96] C. J. Ren, L. N. Zhou, Y. W. Duan, Y. Q. Chen, J. Rare Earths, 2012, 30, 1106-1111.

[97] Z. K. Shi, L. Lan, Y. Z. Li, Y. Yang, Q. Zhang, J. C. Wu, G .Q. Zhang, X. J. Zhao, ACS Sustainable Chem. Eng., 2018, 6, 16503-16514.

[98] Y. Ma, Y. Z. Li, M. Y. Mao, J. T. Hou, M. Zeng, X. J. Zhao, J. Mater. Chem. A, 2015, 3, 5509-5516.

[99] H. H. Liu, Y. Z. Li, Y. Yang, M. Y. Mao, M. Zeng, L. Lan, L. Yun, X. J. Zhao, J. Mater. Chem. A, 2016, 4, 9890-9899.

[100] M. Y. Mao, Y. Z. Li, J. T. Hou, M. Zeng, X. J. Zhao, Appl. Catal. B, 2015, 174-175, 496-503.

[101] S. M. Fang, Y. Z. Li, Y. Yang, J. Chen, H. H. Liu, X. J. Zhao, Environ. Sci.: Nano, 2017, 4, 1798-1807.

[102] J. Chen, Y. Z. Li, S. M. Fang, Y. Yang, X. J. Zhao, Chem. Eng. J., 2018, 332, 205-215.

[103] J. T. Hou, Y. Z. Li, M. Y. Mao, Y. Z. Yue, G. N. Greaves, X. J. Zhao, Nanoscale, 2015, 7, 2633-2640.

[104] X. Xie, Y. Z. Li, Y. Yang, C. Chen, Q. Zhang, Appl. Surf. Sci., 2018, 462, 590-597.

[105] W. K. Ji, T. Shen, J. J. Kong, Z. B. Rui, Y. X. Tong, Ind. Eng. Chem. 
Res., 2018, 57, 12766-12773.

[106] J. S. Zou, Z. C. Si, Y. D. Cao, R. Ran, X. D. Wu, D. Weng, J. Phys. Chem. C, 2016, 120, 29116-29125.

[107] S. C. Cai, J. J. Li, E. Q. Yu, X. Chen, J. Chen, H. P. Jia, ACS Appl. Nano Mater, 2018, 1, 6368-6377.

[108] E. Akarsu, E. Arpaç, J. Hazard. Mater., 2019, 365, 331-339.

[109] S. Hu, B. J.Liu, J. M. Feng, C. Zong, K. Q. Lin, X. Wang, D. Y. Wu, B. Ren, J. Am. Chem. Soc., 2018, 140, 13680-13686.

[110] C. L. Jiang, H. Wang, S. Z. Lin, F. Ma, Y. Q. Wang, H. B. Ji, Ind. Eng. Chem. Res., 2019, 58, 16450-16458.

[111] J. Gao, Z. C. Si, Y. F. Xu, L. P. Liu, Y. Y. Zhang, X. D. Wu, R. Ran, D. Weng, J. Phys. Chem. C, 2019, 123, 1761-1769.

[112] W. K. Ji, Z. B. Rui, H. B. Ji, Ind. Eng. Chem. Res., 2019, 58, 13950-13959.

[113] X. Zhong, J. Sun, S. X. Liu, J. Inorg. Mater., 2011, 26, 1175-1180.

[114] J. J. Li, S. C. Cai, E. Q. Yu, B. Weng, X. Chen, J. Chen, H. P. Jia, Y. J. Xu, Appl. Catal. B, 2018, 233, 260-271.

[115] Y. Y. Zhang, Z. S. Si, J. Gao, Y. X. Liu, L. P. Liu, X. D. Wu, R. Ran, D. Weng, Appl. Surf. Sci., 2019, 469, 246-252.

[116] J. J. Li, E. Q. Yu, S. C. Cai, X. Chen, J. Chen, H. P. Jia, Y. J. Xu, Appl. Catal. B, 2019, 240, 141-152.

[117] X. Chen, S. C. Cai, E. Q. Yu, J. J. Li, J. Chen, H. P. Jia, Appl. Surf. Sci,, 2019, 484, 479-488.

[118] Y. R. Tang, Y. W. Tao, Q. Wang, Z. R. Zhu, W. Q. Zhang, X. Li, A. J. Xie, S. P. Luo, J. Mater. Res., 2019, 34, 3439-3449.

[119] T. H. Tan, J. Scott, Y. H. Ng, R. A. Taylor, K. F. Aguey-Zinsou, R. Amal, ACS Catal., 2016, 6, 1870-1879.

[120] J. C. Kennedy III, A. K. Datye, J. Catal., 1998, 179, 375-389.

[121] D. Jiang, W. Z. Wang, L. Zhang, R. H. Qiu, S. M. Sun, Y. L. Zheng, Appl. Catal. B, 2015, 165, 399-407.

[122] Y. L. Zheng, W. Z. Wang, D. Jiang, L. Zhang, Chem. Eng. J., 2016, 284, 21-27.

[123] J. L. Wang, G. K. Zhang, P. Y. Zhang, Appl. Catal. B, 2018, 239, 77-85.

[124] Y. C. Huang, H. X. Hu, S. X. Wang, M. S. Balogun, H. B. Ji, Y. X. Tong, Appl. Catal. B, 2017, 218, 700-708.

[125] K. Nakano, E. Obuchi, M. Nanri, Chem. Eng. Res. Des., 2004, 82, 297-301.

[126] X. F. Peng, C. H. Wang, Y. Y. Li, H. Ma, F. Yu, G. S. Che, J. Y. Yan, X. T. Zhang, Y. C. Liu, Catal. Today, 2019, 335, 286-293.

[127] Y. Y. Li, C. C. Wang, H. Zheng, F. X. Wan, F. Yu, X. T. Zhang, Y. C. Liu,
Appl. Surf. Sci., 2017, 391, 654-661.

[128] L. Luo, Y. Z. Li, J. T. Hou, Y. Yang, Appl. Surf. Sci., 2014, 319, 332-338.

[129] W. Xie, Y. Z. Li, W. Q. Shi, L. Zhao, X. J. Zhao, P. F. Fang, F. Zheng, S. J. Wang, Chem. Eng. J., 2012, 213, 218-224.

[130] C. Hu, L. Y. Lin, X. X. Hu, J. Environ. Sci., 2006, 18, 76-82.

[131] Y. L. Zheng, W. Z. Wang, D. Jiang, L. Zhang, X. M. Li, Z. Wang, J. Mater. Chem. A, 2016, 4, 105-112.

[132] Y. L. Zheng, W. Z. Wang, D. Jiang, L. Zhang, X. M. Li, Z. Wang, Phys. Chem. Chem. Phys., 2016, 18, 18180-18186.

[133] L. L. Kang, X. Y. Liu, A. Q. Wang, L. Li, Y. J. Ren, X. Y. Li, X. L. Pan, Y. Y. Li, X. Zong, H. Liu, A. I. Frenkel, T. Zhang, Angew. Chem. Int. Ed., 2020, 59, 12909-12916.

[134] J. J. Kong, G. Y. Li, M. C. Wen, J. Y. Chen, H. L. Liu, T. C. An, J. Catal,, 2019, 370, 88-96.

[135] J. Y. Chen, Z. G. He, G. Y. Li, T. C. An, H. X. Shi, Y. Z. Li, Appl. Catal. B, 2017, 209, 146-154.

[136] H. X. Zhong, Y. Wei, Y. Z. Yue, L. H. Zhang, Y. Liu, Nanotechnology, 2016, 27, 135701.

[137] J. Xu, X. M. Li, X. Wu, W. Z. Wang, R. Fan, X. K. Liu, H. L. Xu, J. Phys. Chem. C, 2016, 120, 12666-12672.

[138] Z. R. Lou, D. C. Yuan, F. Y. Zhang, Y. C. Wang, Y. G. Li, L. P. Zhu, Nano Energy, 2019, 62, 653-659.

[139] F. Liu, M. Zeng, Y. Z. Li, Y. Yang, M. Y. Mao, X. J. Zhao, Adv. Funct. Mater., 2016, 26, 4518-4526.

[140] K. Yang, C. Meng, L. L. Lin, X. Y. Peng, X. Chen, X. X. Wang, W. X. Dai, X. Z. Fu, Catal. Sci. Technol., 2016, 6, 829-839.

[141] R. A. Dagle, Y. Wang, G. G. Xia, J. J. Strohm, J. Holladay, D. R. Palo, Appl. Catal. A, 2007, 326, 213-218.

[142] X. H. Lin, K.Yang, R. R. Si, X. Chen, W. X. Dai, X. Z. Fu, Appl. Catal. B, 2014, 147, 585-591.

[143] X. H. Lin, L. L. Lin, K. Huang, X. Chen, W. X. Dai, X. Z. Fu, Appl. Catal. B, 2015, 168-169, 416-422.

[144] K. Cheng, B. Gu, X. L. Liu, J. C. Kang, Q. H. Zhang, Y. Wang, Angew. Chem. Int. Ed., 2016, 55, 4725-4728.

[145] X. N. Guo, Z. F. Jiao, G. Q. Jin, X. Y. Guo, ACS Catal., 2015, 5, 3836-3840.

[146] Y. S. Wang, Y. F. Zhao, J. J. Liu, Z. H. Li, G. I. N. Waterhouse, R. Shi, X. D. Wen, T. R. Zhang, Adv. Energy Mater., 2020, 10, 1902860.

[147] S. Y. Yu, T. Zhang, Y. H. Xie, Q. H. Wang, X. C. Gao, R. F. Zhang, Y. L. Zhang, H. Q. Su, Int. J. Hydrogen Energy, 2015, 40, 870-877.

\title{
光热协同催化去除挥发性有机化合物和CO的研究进展
}

\author{
魏龙福 ${ }^{\mathrm{a}}$, 余长林 ${ }^{\mathrm{a},{ }^{*}}$, 杨 凯 $^{\mathrm{b}}$, 樊启哲 ${ }^{\mathrm{a}}$, 纪红兵 ${ }^{\mathrm{a}, \#}$ \\ a 广东石油化工学院环境科学与工程学院, 化学工程学院, 广东省石油化工污染过程与控制重点实验室, 广东茂名525000

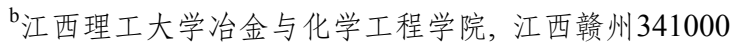

摘要: 随着社会和经济的快速发展, 环境污染和能源短缺等问题, 尤其是空气污染, 已经影响了人类的可持续发展. 挥发性 有机化合物(VOCs), 如苯、甲苯、甲醛和丙酮是主要的空气污染物, 它们主要来源于油漆、有机化学品、石油化工产品、 药物和工业生产过程. 大多VOCs 具有特殊的气味, 而且具有一定的毒性、致畸性和致癌作用, 尤其是苯、甲苯和甲醛等, 会 对人类的身体健康产生巨大的负面作用. 因此, 研发新型高效VOCs处理技术迫在眉睫. 除VOCs外, CO也是非常常见的空 气污染物, 在室温条件下, 它无色无味, 没有刺激性且易燃易爆. $\mathrm{CO}$ 主要来源于煤和石油等含碳材料的不完全燃烧. 在日 常生活中很容易被排放到大气中. 在室温下, $\mathrm{CO}$ 分子是非常稳定的, 很难与其它气体分子发生化学反应. 因此, $\mathrm{CO}$ 的活化 和转化是一项具有挑战性的工作.

催化氧化技术是在催化剂存在的条件下进行的氧化反应, 可以将VOCs直接氧化成为无毒无害的 $\mathrm{CO}_{2}$ 和 $\mathrm{H}_{2} \mathrm{O}$, 也可将 $\mathrm{CO}$ 氧化成 $\mathrm{CO}_{2}$. 光催化技术是一种新型的环境友好型技术, 可在常温常压下进行, 反应条件温和、能耗小、操作简单, 成本 
低, 氧化产物为无毒无害物质, 以及不存在二次污染等优点. 但光催化反应效率较低, 主要通过入射光的能量驱动化学反 应. 热催化则通过升温的方法来驱动化学反应. 目前, 热催化剂主要为贵金属型催化剂, 其具有催化活性较高, 选择性较好 且不存在二次污染等优点. 但高能耗影响产物的稳定性和选择性, 此外, 贵金属的使用导致成本增加. 光热协同催化可以 整合光催化和热催化的优势, 并弥补各自的不足, 形成一种协同效应, 是一种新颖的催化反应.

目前, 关于光催化或热催化高效去除VOCs和CO的综述较多, 但很少有关于光热协同催化高效去除VOCs和CO的综述. 本综述重点讨论光热协同催化高效去除VOCs和CO的最新研究进展. 首先, 介绍了光热协同催化的概况, 如设计光热催化 材料和催化反应器等. 其次, 重点介绍苯、甲苯、乙醇、甲醛、乙醛和丙酮等几种典型VOCs的光热协同催化的最新研究 进展. 再次, 总结了光热协同催化CO加氢和氧化的最新研究进展. 此外, 还探讨了光热协同催化去除VOCs和CO的可能反 应机理. 最后, 对光热协同催化的应用前景进行了展望.

关键词: 挥发性有机化合物; $\mathrm{CO}$; 光催化; 热催化; 光热协同催化

收稿日期: 2020-09-14. 接受日期: 2020-10-09. 上网时间: 2021-03-05.

*通讯联系人. 电话/传真: (0668)2923259; 电子信箱: yuchanglinjx@163.com

\#通讯联系人. 电子信箱: jihb@mail.sysu.edu.cn 基金来源：国家自然科学基金(21961160741，21962006，21707055); 广东省高等学校珠江学者特聘教授资助计划(2019); 广东省 教育厅普通高校重点项目(自然)(2019KZDXM010); 广东省重点研发计划(2019B110206002); 江西省主要学术与学科带头人 (20172BCB22018); 广东省基础与应用基础研究基金(2019A1515011249); 茂名市科技计划项目(2020544); 广东石油化工学院科 研基金项目(2019rc060); 广东省普通高校青年创新人才类项目(2019KQNCX089); 茂名市科技专项资金计划项目(2020KJZX024， 2020KJZX035)..

本文的电子版全文由Elsevier出版社在ScienceDirect上出版(http://www.sciencedirect.com/journal/chinese-journal-of-catalysis). 